\title{
The effect of air pollution on stone decay: the decay of the Drachenfels trachyte in industrial, urban, and rural environments - a case study of the Cologne, Altenberg and Xanten cathedrals
}

\author{
B. Graue $\cdot$ S. Siegesmund $\cdot$ P. Oyhantcabal $\cdot$ \\ R. Naumann $\cdot$ T. Licha $\cdot$ K. Simon
}

Received: 19 August 2012/ Accepted: 29 November 2012/Published online: 30 January 2013

(C) The Author(s) 2013. This article is published with open access at Springerlink.com

\begin{abstract}
Severe stone deterioration is evident at the Cologne cathedral. In particular, the "Drachenfels" trachyte, which was the building material of the medieval construction period, shows significant structural deterioration as well as massive formation of gypsum crusts. The present article investigates crust formation on limestone, sandstone, and volcanic rock from the Cologne cathedral as well as from the Xanten and Altenberg cathedrals. These three buildings, showing varying degrees of deterioration, are located in different areas and exposed to varying industrial, urban, and rural pollution. Thin laminar and black framboidal crusts form on calcareous as
\end{abstract}

B. Graue $(\bowtie) \cdot S$. Siegesmund

Department of Structural Geology and Geodynamics,

Geoscience Center of the University of Goettingen,

Goldschmidtstr. 3, 37077 Goettingen, Germany

e-mail: info@graue.org

P. Oyhantcabal

Department of Geology, Faculty of Sciences,

Universidad de La República,

Igua 4225 CP11400 Montevideo, Uruguay

R. Naumann

Department of Analytic Chemistry and Isotope Geochemistry, German Geo Research Center, Telegrafenberg 14473, Potsdam,

Germany

T. Licha

Department of Applied Geology,

Geoscience Center of the University of Goettingen,

Goldschmidtstr. 3, 37077 Goettingen, Germany

\section{K. Simon}

Department of Geochemistry,

Geoscience Center of the University of Goettingen,

Goldschmidtstr. 1, 37077 Goettingen, Germany well as silicate stone. The lack of a significant intrinsic calcium and sulfur source for the formation of the gypsum crusts on the Drachenfels trachyte indicates major extrinsic environmental impact: a sufficient offer of $\mathrm{SO}_{x}$ from pollutant fluxes as well as external calcium sources (e.g., pollution, mortars, neighboring calcite stones). Chemical analyses reveal strong gypsum enrichment within the crusts as well as higher concentrations of lead and other pollutants (arsenic, antimony, bismuth, tin, etc.), which generally can be linked to traffic and industry. The formation of weathering crusts in an industrial environment is clearly distinguishable from that in rural areas. Scanning electron microscopy observations confirm that the total amount of pollution is less at the Altenberg cathedral than at the Cologne and Xanten cathedrals. XRF analyses show that the formation of gypsum occurs in lower amounts at Altenberg. This correlates well with the measured $\mathrm{SO}_{2}$ content and the intensity of the decay at the different locations. Furthermore, the different types of crusts, e.g., framboidal and laminar, can be differentiated and assigned to the different locations. The black weathering crusts on the silicate Drachenfels trachyte contribute to the degradation of the historic building material. They enhance mechanical moisture-related deterioration processes and the decay by chemical corrosion of rock-forming minerals. Although $\mathrm{SO}_{2}$ concentrations in air have shown a strong decrease over the past 30 years, degradation in connection with weathering crusts is still observed. This indicates that not only contemporary or recent emissions, but also past pollutant concentrations have to be considered.

Keywords Cologne cathedral - Xanten cathedral . Altenberg cathedral - Weathering crusts - Pollution impact . Stone decay processes $\cdot$ Drachenfels trachyte 


\section{Introduction}

The effect of air pollution on stone decay has been a subject in the field of stone deterioration for a long time (Kaiser 1910; Grün 1931; Kieslinger 1932; Winkler 1970; Luckat 1973a, 1984; and listed in Charola and Ware 2002). It is generally accepted that the main pollution-related deterioration processes are gypsum formation and carbonate dissolution (Sabbioni 2003). Most debated is the crust weathering of limestone as a result of the transformation of calcium carbonate into calcium sulfate due to the impact of air pollutant concentration in the atmosphere and the deposition of anthropogenic sulfur (Henley 1967; Sabbioni 2003). Although $\mathrm{SO}_{2}$ concentrations have decreased over the last decades degradation in connection with weathering crusts is still observed. Acid rain, as a result of the contamination of rain water with sulfur, nitrogen oxides and carbon oxides, affects stone material and corrodes rockforming minerals (Martinez and Martinez 1991). Pollution has changed into a complex multi pollutant situation with increasing particulate matter, enhancing the acidic impact in terms of dust deposition (Wolff 1986; Charola and Ware 2002; Brimblecombe 2003). The weathering crusts mainly consist of newly formed minerals, e.g., gypsum, with atmospheric particles embedded within. These can be grouped as porous carbonaceous particles (soot), smooth aluminosilicate particles, and metal particles mainly composed of iron (Del Monte et al. 1981; Esbert et al. 1996; Derbez and Lefèvre 1996). These atmospheric particles derive from different sources; fuel oil combustion of domestic heating and power plants, coal combustion, and gas oil emission (Sabbioni 1995). Vehicle exhaust (Rodriguez-Navarro and Sebastian 1996) and biomass combustion (Ausset et al. 1992) were also identified as sources.

Cologne cathedral is one of the most important cultural monuments of northern Europe and faces severe stone deterioration. The different building stones of the cathedral show a large variety of weathering phenomena. The Drachenfels trachyte, which was the building material of the medieval construction period, shows significant structural deterioration as well as massive formation of gypsum crusts. Already Grün (1931) addressed environmental influence as a factor in the deterioration of the building stones of the Cologne cathedral. Knetsch (1952) described the geological and climatic context in respect to the deterioration of the Cologne cathedral. Luckat and Wolff (Luckat 1973a, 1974, 1975, 1977, 1984; Wolff and Luckat 1973; Wolff 1986; Mirwald et al. 1988) conducted a research program on the influence of air pollutants and especially of flue gas on the deterioration of natural building stones in the 1970s and tested potential preventive conservation treatments. Efes and Lühr (1976) highlighted the influence of environmental pollutants as a significant factor contributing to stone decay. Further studies dealt with the different deterioration processes in several natural building stones of the Cologne cathedral (Kraus 1980, 1985a, b; Kraus and Jasmund 1981; Mirwald et al. 1988; Knacke-Loy 1988, 1989). Kraus (1985a, b) and von Plehwe-Leisen et al. (2007) describe the negative interferences between the original building stone, Drachenfels trachyte and the Krensheimer Muschelkalk. Stronger flaking and exfoliation are observed on the Drachenfels trachyte ashlars placed next to carbonate stone. Wolff (1992) reported on the negative interferences between the Schlaitdorfer sandstone and Londorfer basalt lava, which mainly deteriorates the sandstone and with it the neo-gothic building structure.

In this article, the formation of black weathering crusts as a function of pollution on different building stones in three different environmental settings is discussed. Crust formation on the Drachenfels trachyte, a volcanic rock, in the Cologne cathedral as well as in the Xanten and Altenberg cathedrals, is investigated and compared to crust formation on limestone. Data are compared to those from other sites, including monuments in Hungary, confirming the weathering gradient of natural building stones from a rural to an urban environment.

The cathedrals in Cologne, Xanten, and Altenberg are three major gothic buildings of the Rhineland region, built during the thirteenth and fourteenth centuries using the same construction materials. Construction started in Cologne in 1248 , in Xanten in 1263, and in Altenberg in 1259. The main construction material of the medieval building period was the Drachenfels trachyte from the quarries of the "Siebengebirge". Later restoration and reconstruction phases mainly in the nineteenth century employed similar building materials at all three monuments: "Stenzelberg" latite, "Obernkichen" and "Schlaitdorf" sandstone, and "Krensheimer Muschelkalk" as well as "Londorf" basalt lava. Mortars employed were lime mortars in the medieval period, in the nineteenth century customary cement mortars were in use.

The building stones show severe deterioration phenomena, especially the Drachenfels trachyte (Graue et al. 2011). Thin laminar and black framboidal crusts, which incorporate particles from the pollution fluxes, cover the building stones. Weathering crusts also form on the silicate stone and contribute to the degradation of the historic building material. On the Drachenfels trachyte, the crust formation is strongly correlated to the disintegration of the stone. Gypsum is not only found within the crusts, but also in deeper zones of disintegrated stone material. The crusts tend to detach, and further structural deterioration follows. Contour scaling, flaking and exfoliation are characteristic decay features on the Drachenfels trachyte, leading to 
granular disintegration and crumbling. On the Obernkirchener sandstone and on the Stenzelberg latite weathering crusts form in very thin scales, $2-3 \mathrm{~mm}$ thick, which tend to detach from the stone. The Schlaitdorfer sandstone shows thick black weathering crusts, which are regularly accompanied by severe contour scaling several centimeters thick, as well as pronounced granular disintegration. On the Krensheimer Muschelkalk, the crusts seem to temporarily stabilize the stone surface (Siegesmund et al. 2007). On surfaces exposed to rain, solution phenomena can be observed, e.g., microkarst (Graue et al. 2011).

Although the impact of biological weathering is not investigated in this study, some general aspects of the influence of microorganisms need to be discussed. In general, the presence of microorganisms - such as algae, lichen and fungi-indicates higher humidity, which may enhance deterioration processes (Wihr 1986). Biological deterioration of microorganisms can be divided into biophysical and biochemical deterioration processes (Adamo and Violante 2000; Dornieden and Gorbushina 2000; Pinna and Salvadori 2000; Wierzchos and Ascaso 1998). The extent of biological weathering is dependent on qualitative and quantitative distribution of microorganisms and their metabolic products. The different natural building stones constitute various substrates and provide different living conditions for the organisms (Knöfel 1979).

The colonization of microorganisms results in the formation of alteration patinas on stone surfaces, e.g., on marble mainly consisting of calcium oxalate layers (Jones and Wilson 1985), which are linked to biological weathering (Krumbein 1988; Warscheid et al. 1990). Microorganisms produce organic acids, which may function as acids as well as chelating agents (Jones et al. 2000). This aspect may enhance the feldspar hydrolytic weathering of silicate rock in general.

Another aspect of biological weathering is the colonization with lithotrophic bacteria and fungi. These microorganisms oxidize inorganic substances (Fuchs 2006; Winkler 1975) and may directly support the formation of calcium sulfate dihydrate (Zappia et al. 1998). Out of the lithotrophic bacteria, nitrifying bacteria oxidize nitrous gases $\left(\mathrm{NO}_{x}\right.$-components) to nitric acid, which again contributes to the deterioration of the stone material (Fuchs 2006). Sulfoxidant organisms are very often set in connection to crust formation and stone decay (Frediani et al. 1976; Barcellona-Vero and Montesila 1978).

Pohl and Schneider (2005) mention a possible protecting effect of biofilms on carbonate rocks, which in some cases can also be linked to a preservation function on silicate rocks.

These are only a few aspects of biological weathering or the influence of microorganisms. However, the above points clearly indicate contribution of biological colonization to the deterioration of stone monuments and reveal the broadness and complexity of this topic, which needs further discussion.

The present investigation aims to access the problem of stone deterioration due to weathering crusts related to atmospheric pollution. Mineralogical and geochemical methods are combined; optical microscopy, X-ray diffraction (XRD) and fluorescence (XRF), as well as scanning electron microscopy (SEM), coupled with energy-dispersive X-ray spectroscopy (SEM-EDX) and wavelength dispersive microprobe analyses (WDS). Furthermore, laser ablation inductively coupled plasma mass spectrometry (LA-ICP-MS) and inductively coupled plasma optical emission spectrometry (ICP-OES) as well as ion chromatography analyses with spectroscopy (IC) are used to address the issue. Polycyclic aromatic hydrocarbons (PAH) are determined by microwave accelerated extraction and subsequent gas chromatography with mass spectrometric detection (MAE-GC-MS).

\section{Environmental settings}

The three buildings are located in very different environmental settings (Fig. 1). Cologne cathedral $(53 \mathrm{~m}$ above $\mathrm{NN}$ ) is located in a metropolitan center with one million inhabitants next to the river Rhine. Xanten cathedral
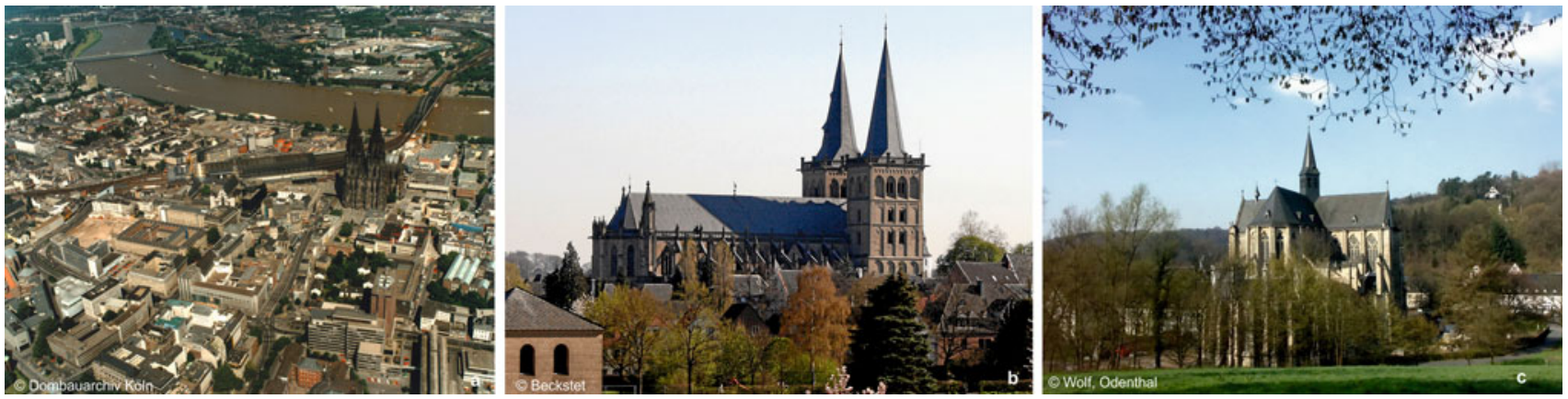

Fig. 1 The cathedrals and their environmental settings: a Cologne, b Xanten, c Altenberg 
( $22 \mathrm{~m}$ above $\mathrm{NN}$ ) is the Catholic church of a small city on the Lower Rhine with 18,000 inhabitants and with smaller industrial effects (Arnhem, NL), while Altenberg cathedral (149 $\mathrm{m}$ above $\mathrm{NN}$ ) is situated in a greenfield setting surrounded by forested mountains in the "Bergisches Land".

Middle Europe belonging to the mid-latitudes has a damp, cool temperate climate. The western German climate shows a maritime influence due to its geographical proximity to the North Sea and the Atlantic, and therefore the Gulf Stream has an impact through the West Wind Drift (Lauer and Bendix 2004). This geographic position provides mild winters and moderate summers. Temperature, relative humidity, and rainfall at the three locations differ only a little (Table. 1). The mean annual temperature is 11.4 ${ }^{\circ} \mathrm{C}$ in Cologne, $10.6{ }^{\circ} \mathrm{C}$ in Xanten, and $7.1{ }^{\circ} \mathrm{C}$ in Altenberg. Warmest months are July and August; coldest months are January and December, with temperatures around -10 to $+30{ }^{\circ} \mathrm{C}$ and relative humidity ranging between 65 and $95 \%$. The relative humidity shows highest annual values of 90-95\% in winter (November-February) and lowest annual values for April-August from 65 to $75 \%$ (Table 1). Climate data from Hungary show less maritime but more continental influence.

The buildings are exposed to ubiquitous air pollutants of anthropogenic origin. These are mainly gaseous pollutants like $\mathrm{SO}_{2}$ and $\mathrm{NO}_{\mathrm{x}}$. Concentrations of both of these have decreased over the last decades, causing an increase in precipitation $\mathrm{pH}$ (Fig. 2). The effect of particulate matter in the form of settling dust shows continuously steady values. $\mathrm{SO}_{2}$ shows highest annual values in the winter months (December-March) and lowest annual values in August.

Data for the $\mathrm{SO}_{2}$-fluxes show a strong decrease over the past 30 years, with a comparable impact for Cologne and Xanten and a lower influence in Altenberg. The particulate matter (PM10) has been monitored since 2003/2004 and shows the highest values for Xanten and the lowest for Altenberg. The relatively high values for Xanten in comparison to Cologne may be explained by a certain pollution impact from the bigger city of Arnhem, NL, from which pollution fluxes are transported with west winds. Also Altenberg is subject to west winds and therefore, to a certain impact by the pollution fluxes of the industrial area of Cologne, Leverkusen, and Düsseldorf. In general, the comparably low values for Altenberg reflect a low impact region of an arborous rural area. The Cologne cathedral is located in the city center next to the main railway station, which has served as an active traffic interchange since the industrial era. Within the city of Cologne there are four power plants, and $15 \mathrm{~km}$ south west of Cologne is a larger coal-fired power plant.

\section{Analytical techniques}

To understand the context of building stone diversity and the different deterioration features, a sample field at Cologne cathedral was mapped analogous to the system developed by Fitzner et al. (1995). Samples from crusts and dust as well as unweathered and weathered rock samples were collected from the Cologne, Xanten, and Altenberg cathedrals from the different building stones (Drachenfels trachyte, Obernkirchner sandstone, Krensheimer Muschelkalk).

Sample preparation and sample analyses were performed on the different sample types using overlapping techniques in mineralogical and geochemical analyses whenever possible. Thin sections perpendicular to the exposed surface of the rock were prepared and textural analysis of thin sections was performed by polarizing microscopy. The chemical data presented focus on $\mathrm{C}, \mathrm{Na}$, $\mathrm{Mg}, \mathrm{Si}, \mathrm{S}, \mathrm{K}, \mathrm{Ca}, \mathrm{Al}, \mathrm{Ti}, \mathrm{Mn}, \mathrm{Fe}, \mathrm{Zn}, \mathrm{As}, \mathrm{Sb}, \mathrm{Pb}, \mathrm{Bi}$ contents of the host rocks and crusts.

The chemical composition was obtained by XRF spectroscopy. Major element oxides and the trace elements $\mathrm{Ba}$, $\mathrm{Cr}, \mathrm{Ga}, \mathrm{Nb}, \mathrm{Ni}, \mathrm{Rb}, \mathrm{Sr}, \mathrm{V}, \mathrm{Y}, \mathrm{Zn}$, and $\mathrm{Zr}$ were analyzed by $\mathrm{XRF}$ on $105^{\circ} \mathrm{C}$-dried samples, prepared as fused disks of lithium tetraborate-metaborate (FLUXANA FX-X65, sample-to-flux ratio 1:6). A PANalytical Axios Advanced wavelength-dispersive spectrometer and matrix correction programs were used to calculate concentrations. $\mathrm{H}_{2} \mathrm{O}^{+}$and $\mathrm{CO}_{2}$ were determined using a Vario EL III (Elementar Analysensysteme $\mathrm{GmbH}$, Hanau/Germany). An ELTRA CS 2000 (ELTRA GmbH Neuss) is used for measuring sulfur.

The mineralogical composition of the samples (black crusts and dust) was determined by XRD. Powder X-ray patterns were obtained using a PANalytical Empyrean powder diffractometer with $\mathrm{Cu} \mathrm{K} \alpha$ radiation, automatic divergent and antiscatter slits and a PIXcel ${ }^{3 \mathrm{D}}$ detector.
Table 1 Climate and annual mean concentration of air pollutants for Cologne, Xanten, and Altenberg as well as general data from Hungary (data compilation from Török et al. 2011; LANUV 2010; WMOUN 2012)

\begin{tabular}{lllll}
\hline Parameter & Cologne & Xanten & Altenberg & Hungary \\
\hline Mean annual temperature & $11.4{ }^{\circ} \mathrm{C}$ & $10.6{ }^{\circ} \mathrm{C}$ & $7.1{ }^{\circ} \mathrm{C}$ & $10.3{ }^{\circ} \mathrm{C}$ \\
Min/max temperature & $-10.8 / 29.9{ }^{\circ} \mathrm{C}$ & $-14.6 / 29.0{ }^{\circ} \mathrm{C}$ & $-17.3 / 27.4{ }^{\circ} \mathrm{C}$ & $-12 /+42{ }^{\circ} \mathrm{C}$ \\
Annual precipitation & $520-850 \mathrm{~mm}$ & $490-890 \mathrm{~mm}$ & $920-1,690 \mathrm{~mm}$ & $550-600 \mathrm{~mm}$ \\
Coldest/warmest month & July/January & July/December & July/December & July/December \\
\hline
\end{tabular}




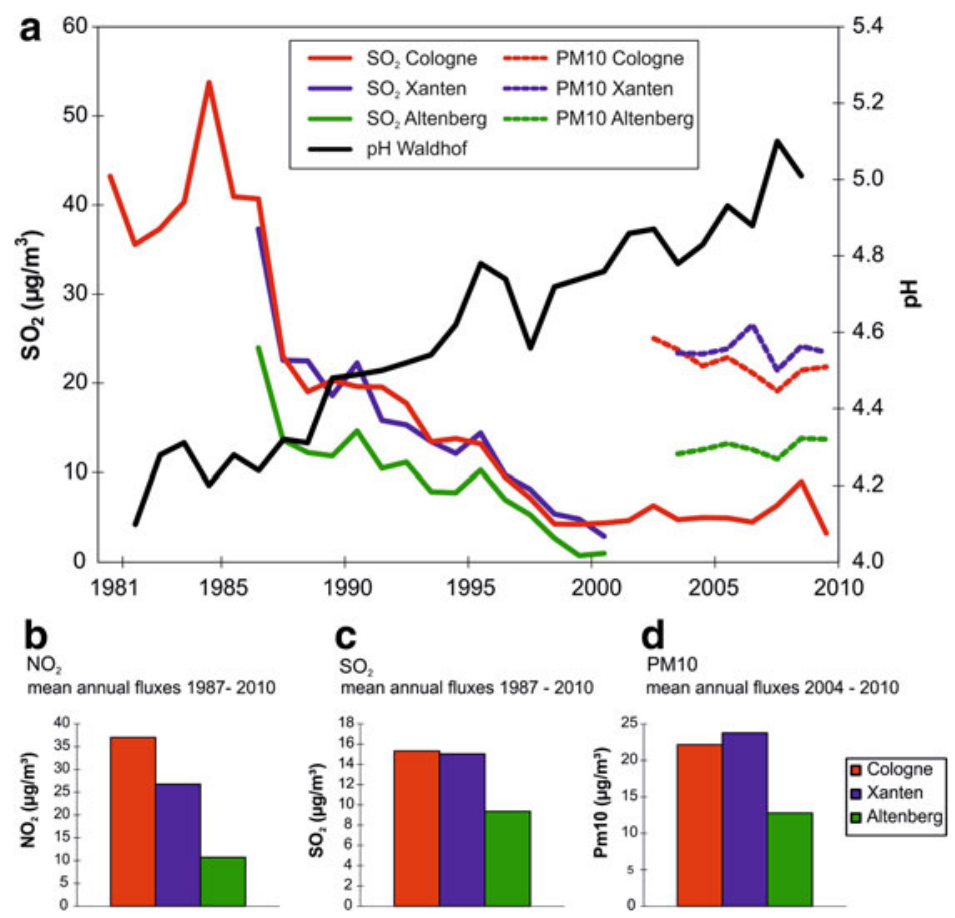

Fig. 2 a $\mathrm{SO}_{2}$ and PM10 fluxes of industrial (Cologne), urban (Xanten), and rural (Altenberg) locations versus $\mathrm{pH}$ precipitation (Waldhof), 1981-2010 (mean annual fluxes) (LANUV 2010; UBA 2011); b-d Mean annual fluxes from industrial, urban, and rural environment: b $\mathrm{NO}_{2}$ from 1987 to 2010; c SO from 1987 to 2010; d PM10 from 2004 to 2010. Data are based on measuring stations from Landesamt für Umwelt, Natur und Verbraucherschutz Nordrhein-Westfalen (LANUV). For Cologne, the data were acquired from

The diffraction data were recorded from $5^{\circ}$ to $85^{\circ} 2 \theta$ via a continuous scan with a step-size of 0.013 and a scan time of $60 \mathrm{~s}$ per step. The generator settings were $40 \mathrm{kV}$ and $40 \mathrm{~mA}$. The Rietveld algorithm BGMN was used for quantitative analysis (Bergmann et al. 1998).

Laser ablation inductively coupled plasma mass spectrometry analyses were performed on thin slices of the samples. The laser used was a Compex 110 Excimer (ArF $193 \mathrm{~nm}$ ) by Lambda Physic (Goettingen, Germany), a GeoLas optical bench by MikroLas (Goettingen, Germany), a small volume sample chamber, an ablation pit with a diameter of $120 \mu \mathrm{m}, 10 \mathrm{~Hz}$ repetition rate for the laser pulses, and about $3 \mathrm{~J} / \mathrm{cm}^{2}$ available energy. The mass spectrometer was a Perkin Elmer DRC II (Siex, Canada). Calibration was done using NBS610 (NIST, USA), internal Standard $43 \mathrm{Ca}$, dwell time $10 \mathrm{~ms} /$ isotope, $0.925 \mathrm{~s}$ per sweep, and a total of 250 sweeps giving a total measurement time of $3 \mathrm{~h}$ and $50 \mathrm{~min}$. Measured isotopes were: Li7, Na23, Mg24, Mg25, Al27, Si29, P31, S34, Cl35, K39, Ca43, Sc45, Ti47, Ti49, V51, Cr53, Mn55, Fe57, Co59, Ni60, Cu63, Cu65, Zn66, Ga71, Ge73, As75, Rb85, Sr88, Y89, Zr90, Nb93, Mo9.

To visualize the microfabric of the crust and the host rock and to detect elemental-mineralogical composition of the LANUV station in Cologne-Rodenkirchen at a distance of $6 \mathrm{~km}$ from the cathedral. For Xanten, local data were available from the LANUV station in Wesel at about $13 \mathrm{~km}$ distance from Xanten cathedral on the other side (east bank) of the river Rhine. For Altenberg the data of several LANUV stations were compared and the data of Netphen in the Rothaargebirge $(70 \mathrm{~km}$ east from Altenberg also in a rural hilly and forested region) showed similar values

samples, SEM-EDX techniques were applied on thin sections as well as on small fragment samples (LEO GEMINI SEM 1530 and LEO 1455 Gemini as well as AMRAY 1630). EDX-analyses were performed on a Quantra 200F (Fei) with a field emission cathode with an initial voltage of $20 \mathrm{kV}$ (Department of Crystallography, Geoscience Center University of Goettingen, Germany).

Wavelength dispersive microprobe analyses were performed with a JEOL JXA 8900 RL instrument (Department of Geochemistry, Geoscience Center University of Goettingen, Germany). For quantitative measurements, $15 \mathrm{kV}$ acceleration voltage, $15 \mathrm{nA}$ beam current on the Faraday cup, a defocused beam of $3.5 \mu \mathrm{m}$, and counting times between $15 \mathrm{~s}$ on the peak for $\mathrm{Na}, \mathrm{Mg}, \mathrm{Al}, \mathrm{Si}, \mathrm{K}, \mathrm{Ca}$, and $\mathrm{Fe}$ and $30 \mathrm{~s}$ for $\mathrm{P}, \mathrm{S}, \mathrm{Ti}$, and $\mathrm{Ba}$ were chosen. Data processing was done with the CITZAF routine in the JEOL software, which is based on the $\Phi(\rho \mathrm{Z})$ correction method (Armstrong 1991, 1995). The following standards were used for the analysis: Albite for $\mathrm{Na}, \mathrm{MgO}$ (synthetic) for $\mathrm{Mg}$, anorthite for $\mathrm{Al}$, wollastonite for $\mathrm{Si}$ and $\mathrm{Ca}$, sanidine for $\mathrm{K}$, apatite for $\mathrm{P}$, baryte for $\mathrm{S}, \mathrm{TiO}_{2}$ (synthetic) for $\mathrm{Ti}$, rhodonite for $\mathrm{Mn}$, haematite for $\mathrm{Fe}$ and celsian for Ba. Detection limits are calculated from the error propagation of the two measurements of the background signals of each X-ray line 


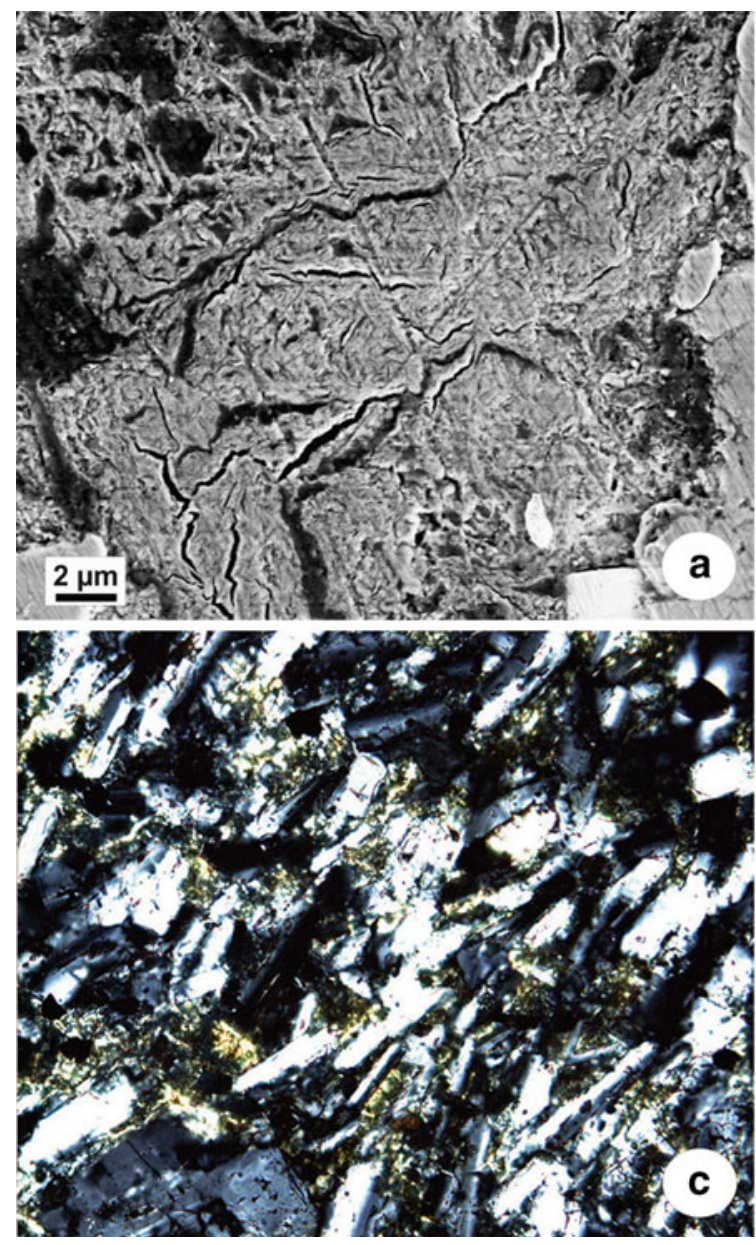

Fig. 3 a Secondary electron picture of Drachenfels trachyte: altered volcanic glass fractions in the interstitial areas are much fractured showing a very distinct porosity; b the fluidal structure of the groundmass produces several textural domains with preferred orientation of the groundmass feldspar laths (marked with red arrows;

and are given as a 2-sigma value. The element distribution of $\mathrm{Mg}, \mathrm{Al}, \mathrm{K}, \mathrm{Ca}, \mathrm{Fe}$ (WDS) and $\mathrm{S}, \mathrm{Si}$ (EDS) was mapped using an acceleration voltage of $15 \mathrm{kV}$ and beam current of $30 \mathrm{nA}$. The acquisition time was set to $50 \mathrm{~ms}$ per step. The scan grid was spaced at $0.5 \mu \mathrm{m}$ per step, covering in total $400 \times 400$ steps. Simultaneous acquisition of the backscatter signal in composition mode was performed.

For PAH analysis, the pulverized rock samples $(1 \mathrm{~g})$ were weighted into Teflon vessels, internal standards (acenaphthen D 10, phenanthren D 10, pyren D 10, chrysen D 12, perylen D 12, and bBenzo (g,h,i) perylen D 12) and $5 \mathrm{~mL}$ isohexane/acetone (3:1 v:v) were added and subsequently extracted on a MARS XPRESS microwave system at $130{ }^{\circ} \mathrm{C}$ for $20 \mathrm{~min}$. After cooling, the supernatant was removed and transferred into purging vials and after the addition of $500 \mu \mathrm{L}$ toluene purged in a gentle stream of nitrogen until dry. The remains were redissolved into $500 \mu \mathrm{L}$ toluene, transferred into autosampler vials and

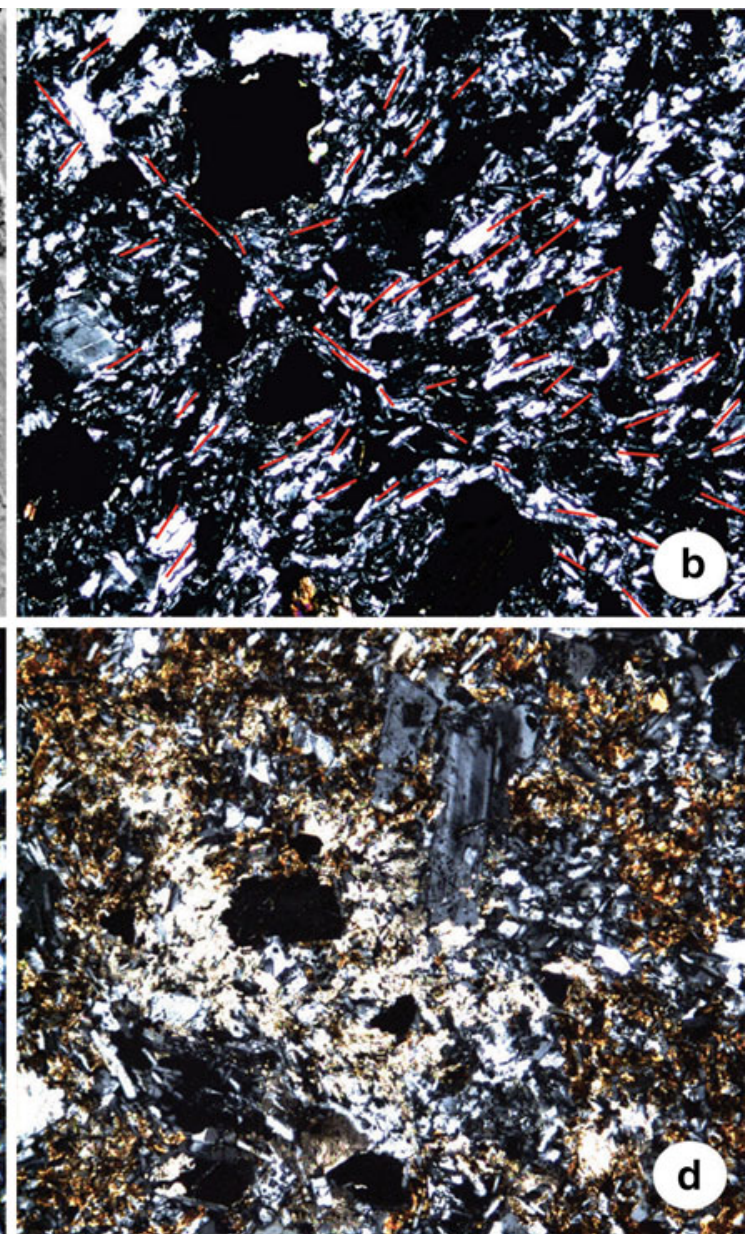

crossed polars; image width $1.68 \mathrm{~mm}$ ); c recrystallized and altered volcanic glass fractions in an unweathered rock sample, showing high interferences in crossed polars (marked with arrow; image width 0.42 $\mathrm{mm}$ ); $\mathbf{d}$ accumulation of calcite and Fe-oxides as a result of alteration processes (crossed polars; image width $1.68 \mathrm{~mm}$ )

centrifuged at 5,000 rpm for $10 \mathrm{~min}$. They were then immediately analyzed on a GC-MS (Agilent 7890A, 5975E). Separation of the analytes was achieved using a Varian VF5-ms column $(30 \times 250 \times 0.25)$ and a steady temperature gradient of $6 \%$ min up to a final temperature of $325^{\circ} \mathrm{C}$. Data were recorded in single ion monitoring mode (quantifier in parenthesis) with a dwell time of at least $50 \mathrm{~ms}$ per amu for the following analytes: acenaphthylen (152), fluorene (166), phenanthrene (178), anthracenene (178), pyrene (202), 7H-benzo-fluorene (216), cyclopenta(c,d)pyrene (226), benzo(a)anthracene (228), chrysene (228), 5 -methyl-chrysene (242), benzo (b,j,k) fluoranthene (252), benzo(a)pyrene (276), indeno(1,2,3-cd)-pyren (278), dibenzo(a,h)-anthracene (276), benzo(g,h,i)-perylene (302), dibenzo(a,l)-pyrene (302), dibenzo(a,e)-pyrene (302), dibenzo(a,i)-pyrene (302), dibenzo(a,h)-pyrene (302). Quality was assured by simultaneous scanning 50-350 amu. The method quantitation limit was $1 \mu \mathrm{g} / \mathrm{kg}$. 

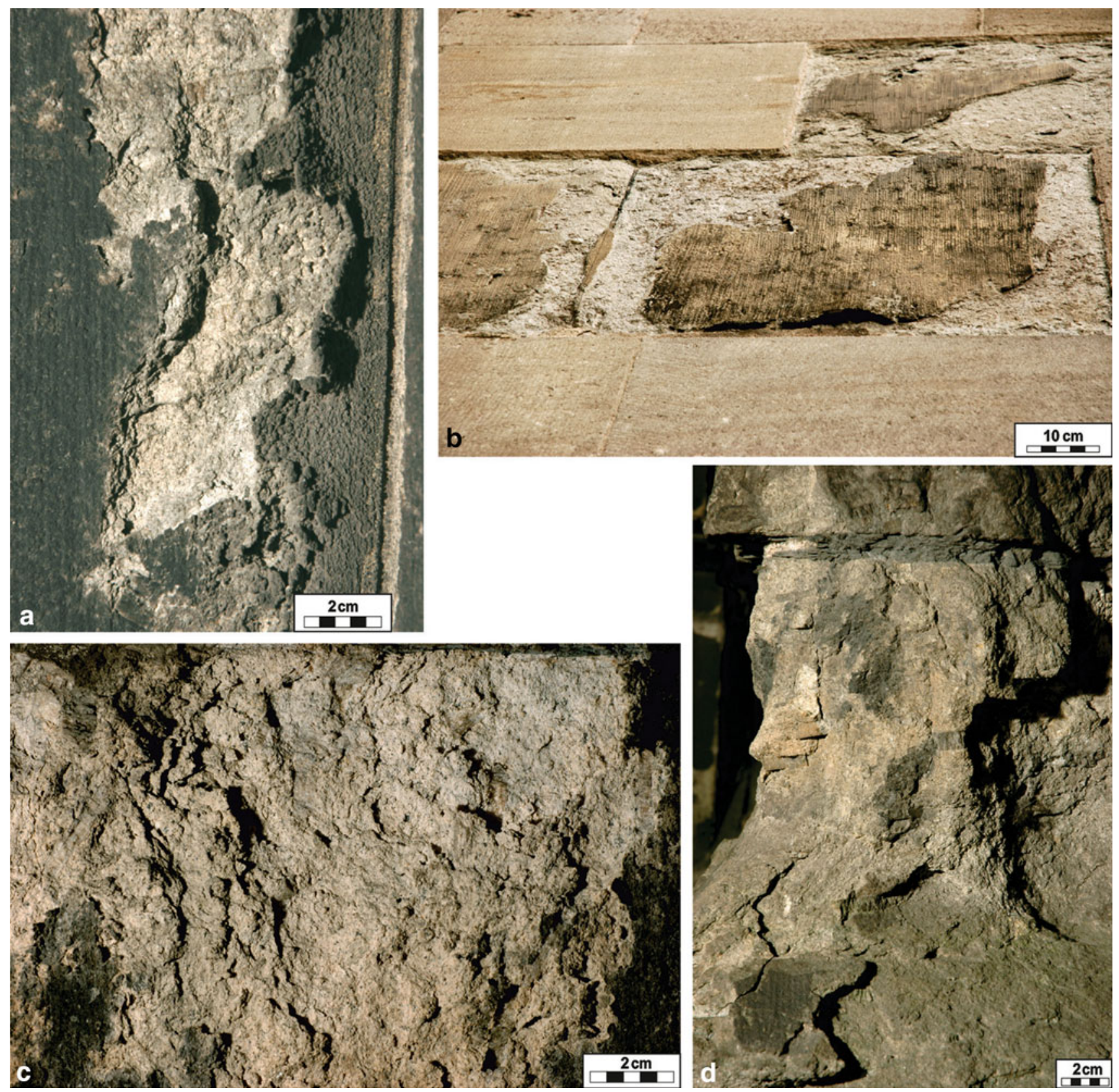

Fig. 4 Weathering forms of Drachenfels trachyte. a Framboidal weathering crust, showing bulging and flaking of the rock underneath; b deformed and detached scale; c surface deterioration and flaking; $\mathbf{d}$ structural disintegration and crumbling to total fabric collapse

\section{The Drachenfels trachyte and its decay features}

The Drachenfels trachyte, used for construction in the Rhineland since Roman times (Berres 1996; Wolff 2004), was the main construction material for the three investigated buildings. The trachyte has a medium porosity of $11.9-13.4 \%$ and is of light gray color (Graue et al. 2011). Two different varieties of Drachenfels trachyte can be distinguished macroscopically: a partially pale grayish one and a yellowish reddish porphyritic trachyte (Simper 1990). The fabric of the trachyte can be divided into three different fabric elements: the very large phenocrysts of sanidine, up to $7 \mathrm{~cm}$ in size, are a characteristic feature of the stone. Plagioclase phenocrysts are observed as well. Secondly, a micro- to cryptocrystalline groundmass consists of mainly feldspar laths and quartz. Thirdly, altered volcanic glass fractions as interstitial material between the small feldspar laths of the groundmass form a mesostasis. These interstitial areas of recrystallized glass are much fractured with a high and distinct porosity (Fig. 3a). The Drachenfels trachyte has a classical porphyry fabric: the large-oriented phenocrysts are embedded in a very fine 
crystalline fluidal groundmass. The sanidine phenocrysts show a preferred orientation, tracing the flow fabric due to the former flow direction of the magma. The small lathshaped feldspars flow around the large idiomorphic crystals, with the result that several textural domains with preferred orientation of the groundmass feldspar laths exist (Fig. 3b). The sanidine as well as the plagioclase phenocrysts show significant crack formation, which can be considered as a secondary porosity. This probably traces back to geological relaxation processes during the rise of the magma.

The rock mainly consists of sanidine (50 wt. \%), plagioclase (24 wt. \%) and quartz (13 wt. \%). Other components are augite (5 wt. \%) and biotite (5 wt. \%) and common accessory minerals are ore $(2 \mathrm{wt} . \%)$ and apatite, zircon and sphene (1 wt. \%) (Vieten 1961). The sanidine phenocrysts often show Carlsbad twins and oscillatory zonation. Biotite is often strongly altered. The micro- to cryptocrystalline groundmass (64 wt. \%) consists of feldspar and quartz (Simper 1990). The plagioclases are zonal structured and contain about $30 \mathrm{~mol} \%$ anorthite $\left(\mathrm{Ab}_{70} \mathrm{An}_{30}\right)$ (Kraus 1985a, b). The interstitial volcanic glass fractions are often recrystallized and altered to montmorillonite (Koch 2006) (Fig. 3c). Vieten (1961) detected 1-5 wt. \% montmorillonite in samples from different outcrops at the Drachenfels. In places, calcite occurs in contiguity with Fe-oxides (Fig. 3d) indicating alteration processes.

The different building stones of the Cologne cathedral show a large variation of weathering phenomena. In particular, the Drachenfels trachyte shows severe deterioration in the form of cracks, surface deterioration, and backweathering coexisting with flaking, exfoliation, and structural disintegration to crumbling and the massive formation of gypsum crusts (Fig. 4a) (Graue et al. 2011). The flaking can occur in a very pronounced fashion (von PlehweLeisen et al. 2007), which eventually leads to structural disintegration and complete material loss (Fig. 4c).
Back-weathered areas often display stronger further decay in terms of microcracks, crumbling to total fabric collapse (Fig. 4d). Scaling is observable and very often shows a granular disintegrated zone on the reverse side of the scale, whereas the original stone surface generally still exists (Fig. 4b). Formation of fissures may also propagate many centimeters in depth into the stone. The flow direction of the Drachenfels trachyte, which is indicated by the orientation of the large crystals of sanidine, has a certain impact onto the weathering behavior of the stone. In the Drachenfels trachyte, the deterioration is more intense when the flow fabric is parallel to the visible surface of the building stone, i.e., the preferred orientation of sanidines is surface parallel. Sanidine crystals and the groundmass matrix often show different weathering behavior depending on the mounting direction of the building stone. The large crystals are either weathered-out or are protruding due to the loss of the surrounding matrix. A third variation is the surface parallel weathering of components, matrix and phenocrysts (surface parallel-oriented) show a simultaneous back weathering.

On the Drachenfels trachyte, the formation of thin laminar crusts as well as thick framboidal crusts is observed (Fig. 4a). Black framboidal crusts tend to bulge out and detach from the stone surface. The stone structure in the background of these crusts is strongly weakened and disintegrates in the form of multiple flaking, exfoliations, and further crumbling. Thin laminar crusts often build up on structurally intact stone surfaces but contour scaling often accompanies this. These surface parallel scales show a thickness of a few millimeters to $1-2 \mathrm{~cm}$ with the formation of a brittle disaggregated zone on the back.

\section{Crust classification}

The deposition of airborne particulates and the formation of crusts can be observed on surfaces over the entirety of
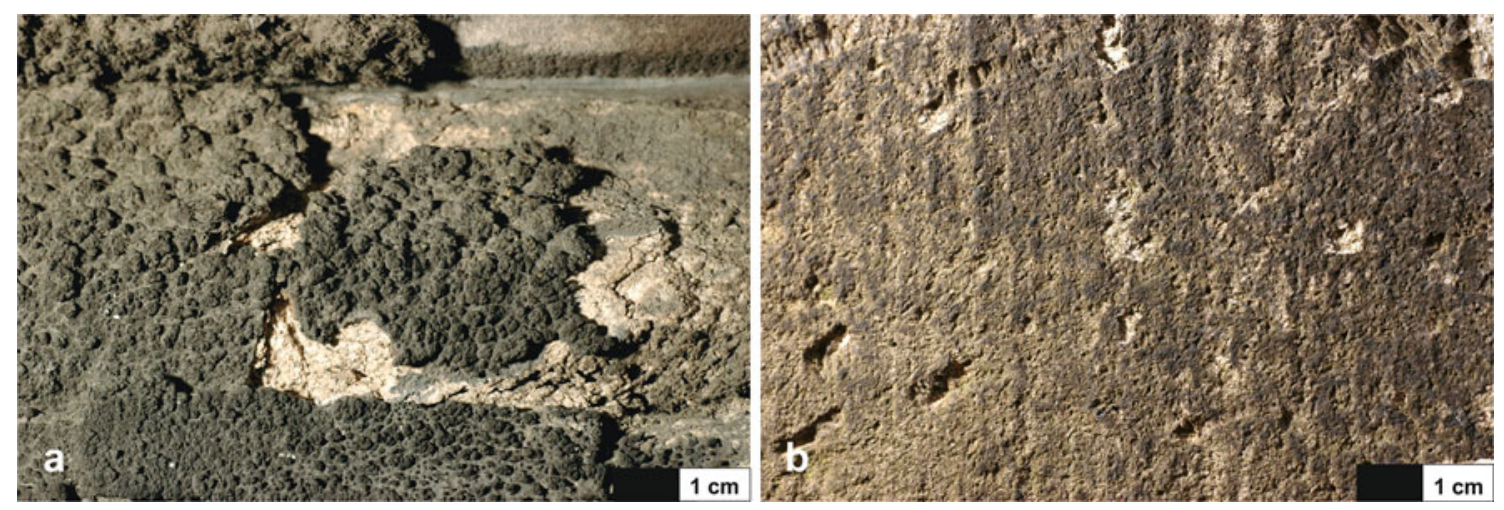

Fig. 5 a Cauliflower-like or framboidal crust on Drachenfels trachyte contributing to the disintegration of the stone leading to flaking and material loss; b laminar crust on Drachenfels trachyte tracing the stone surface where working traces are still visible 

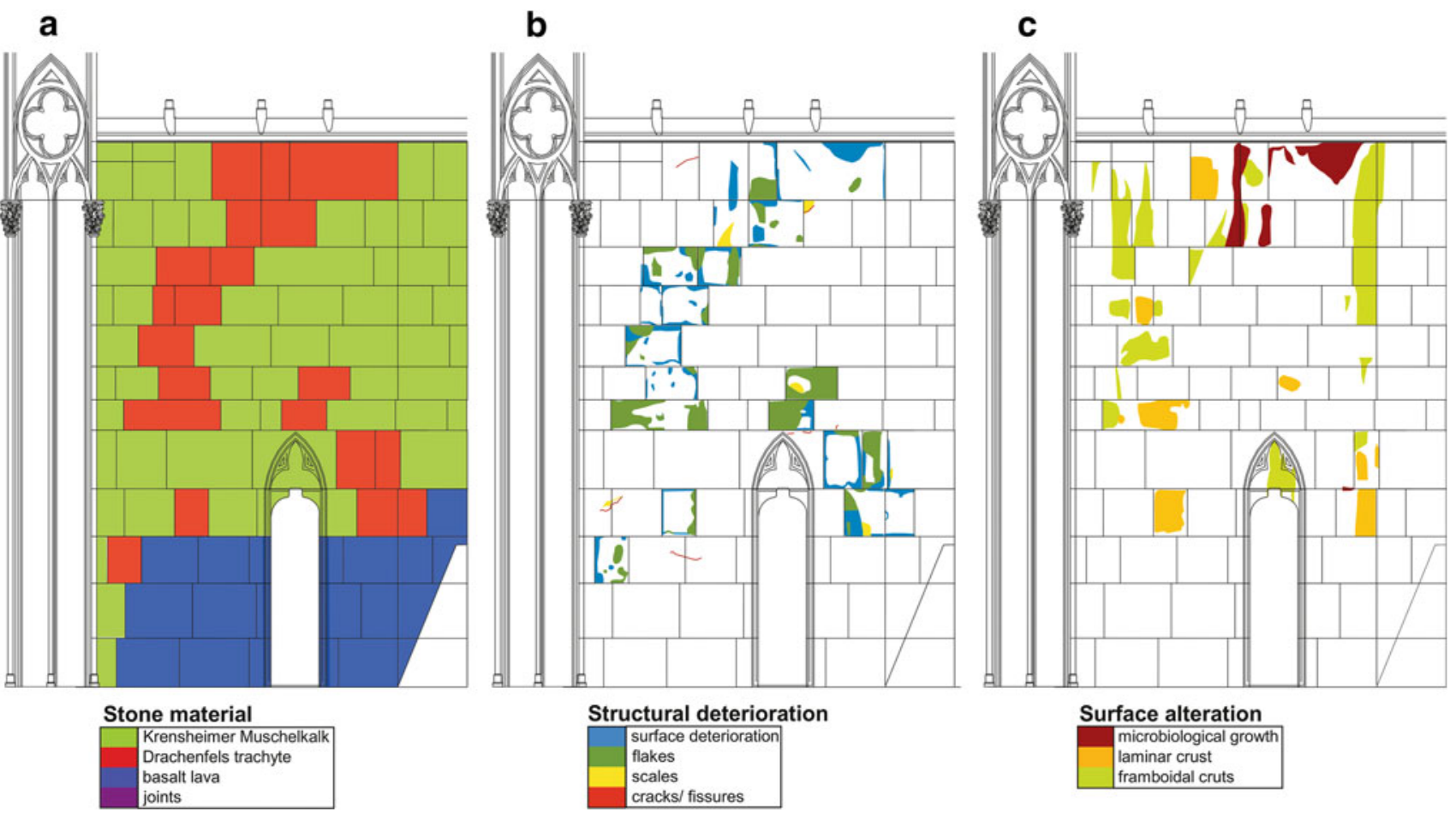

Fig. 6 Mapping of a flying buttress of the choir at Cologne cathedral; a lithology: Drachenfels trachyte (red), Krensheimer Muschelkalk (green), basalt lava (blue), joints (purple); b structural deterioration: surface deterioration (light blue), flaking (green), scaling (yellow), cracks (red); c surface alteration: microbiological infestation (dark red), laminar crusts (orange), framboidal crusts (light green)
Cologne cathedral. These surface deterioration features appear in different manifestations from patina-like grayish black surface depositions and soiling to thin black laminar crust and thick framboidal- or cauliflower-like black crusts. Especially in context with framboidal crusts surface detachment and loss as well as further disintegration is observed (Fig. 5a). These cauliflower-like weathering crusts vary extremely in thickness from 2 to 15 and even $30 \mathrm{~mm}$ (Török et al. 2011). Their specific morphology also describes them as dendritic (Török et al. 2011), globular (Bonazza et al. 2007), ropey (Antill and Viles 1999), or framboidal (Török 2003, 2008). They display globular or rosette-like formations of gypsum crystals. Calcareous and also quartz particles cover the stone surface and organic as well as inorganic particles from the pollution fluxes are incorporated into the crusts. Framboidal crusts generally build up in sheltered to moderately exposed areas as well as in cavities on vertical stone surfaces. They are often observed at different sites and for different building stones (Amoroso and Fassina 1983; Camuffo 1995; Sabbioni 1995; Bonazza et al. 2004, 2007).

Thin laminar black crusts trace the stone surface and may cover complete sections of the building's structure not necessarily preferring protected sites (Fig. $5 \mathrm{~b}$ ). This kind of crust does not change the morphology of the stone surface (Fitzner et al. 1995) and seems to have very strong bonds with the stone surface (Török et al. 2011; Siegesmund et al. 2007). Scaling is often observed in context with laminar crusts.

Other investigated building stones of Cologne cathedral also show crust formation. On the Schlaitdorfer sandstone massive gypsum crusts build up due to the carbonate cement (app. $14 \%$ ) leading to characteristic disintegration in the form of scaling, flaking, and granular disintegration into sand (Lukas 1990). The main deterioration phenomenon of Stenzelberg latite is a typical formation of scales with a thickness of 2-3 mm (Graue et al. 2011). Obernkirchner sandstone has a high weather resistance, but shows black crusts and the formation of gypsum crusts in posterior and sheltered areas. Krensheimer Muschelkalk as a carbonate building stone shows massive gypsum crust formations. This is visible in rain-protected areas, while on surfaces exposed to rain, solution phenomena can be observed, e.g., microkarst. Unlike the Drachenfels trachyte, the limestone shows no structural disintegration with crust formation. At first, it has almost a consolidating or inhibiting function.

In order to describe the variations of the different building stones and the specific deterioration features, a representative survey area has been mapped in accordance with the classification by Fitzner et al. (1995) (Fig. 6). The building material and the deterioration phenomena-surface deterioration, gypsum crusts, scaling, flaking, cracks and 

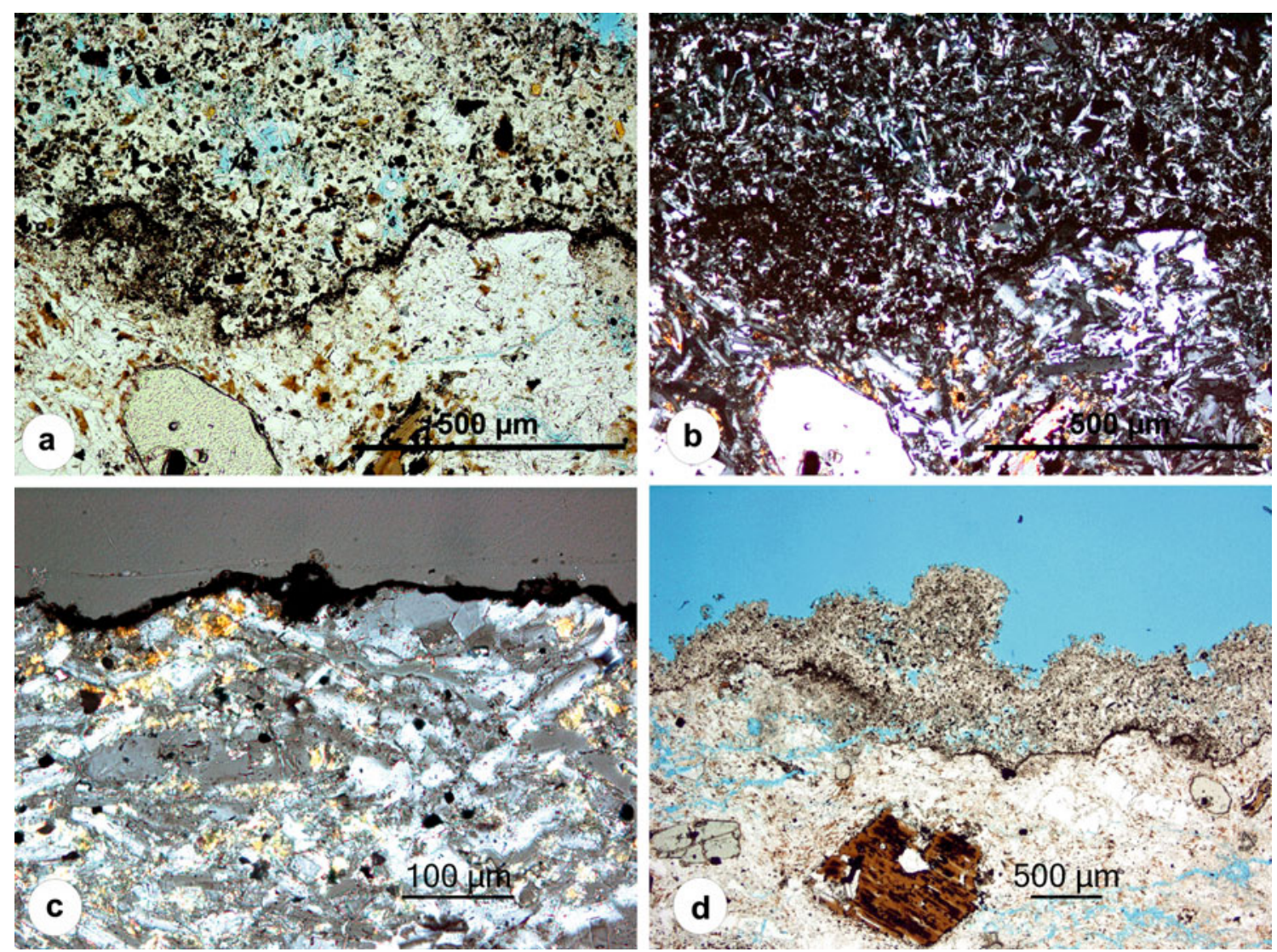

Fig. 7 Black weathering crusts on Drachenfels trachyte a framboidal crust (transmitted light) black interface layer, very porous polymineral composition with heterogeneous particle size; b framboidal crust-same detail as Fig. 7a (crossed polars); c laminar crust on

depositions-have been mapped displaying their distribution within the selected wall area. The detailed map illustrated in Fig. 6 shows a section on the northern pillar of the flying buttresses of the choir, indicating that the major deterioration is on the Drachenfels trachyte.

If the three cathedrals from the industrial (Cologne), urban (Xanten), and rural (Altenberg) locations are compared, they show clear differences in terms of deterioration gradients and crust formation. While Altenberg cathedral shows only very little stone deterioration, in Xanten and especially in Cologne the decay is significant. At Cologne cathedral, severe damage can be observed entailing static disturbances. At all three cathedrals, scaling and flaking are the main deterioration features, though the observed effect is less at Xanten and Altenberg. As the mapping shows (Fig. 6), scaling and flaking are mainly concentrated in the Drachenfels trachyte. At Xanten and Altenberg cathedrals the deterioration is often located in superficial areas of the building stones of Drachenfels trachyte, reaching into the stone material only for several centimeters in depth. Here, it seldom reaches such a significant depth where the structural disintegration comprises crumbling and total
Drachenfels trachyte, very thin opaque surface layer (crossed polars); d thick framboidal crust with a black interface layer and surface parallel cracks in the host rock (crossed polars)

fabric collapse, as seen at Cologne cathedral. The same can be ascertained for the intensity of surface soiling and weathering crusts. At Cologne cathedral, weathering crusts on building stones become apparent whether as dark brownish-black surfaces of a mostly already detached stone surface or as framboidal crusts with a disintegrated stone matrix underneath (Fig. 5). In Xanten weathering, crusts are more to be addressed as thin laminar crusts or soiling on a mostly structurally intact original building stone surface. The current condition of Altenberg cathedral reflects the extensive restoration and repair works carried out since the 1990s. Nevertheless, previous investigations only detected black weathering crusts to a minor degree (IBS 1990).

\section{Mineralogy and fabric of black weathering crusts}

Microscopic observation reveals high porosity of the framboidal crusts (Fig. 7a) and very small (10-50 $\mu \mathrm{m})$ and evenly spread acicular gypsum crystals (Fig. 7b). Cavities within the crystals cause the high porosity of the crust. The crust contains a significant amount of widely spread 
Fig. 8 Surface detections of black weathering crusts on Drachenfels trachyte: a SEM picture (SE detection) of the outer surface of a framboidal crust; $\mathbf{b}$ EDX spectrum of the outer surface of a framboidal crust; c EDX map (calcium) of the outer surface of a framboidal crust; $\mathbf{d}$ EDX map (sulfur) of the outer surface of a framboidal crust; e SEM picture (SE detection) of the outer surface of a laminar crust; $f$ EDX spectrum of the outer surface of a laminar crust
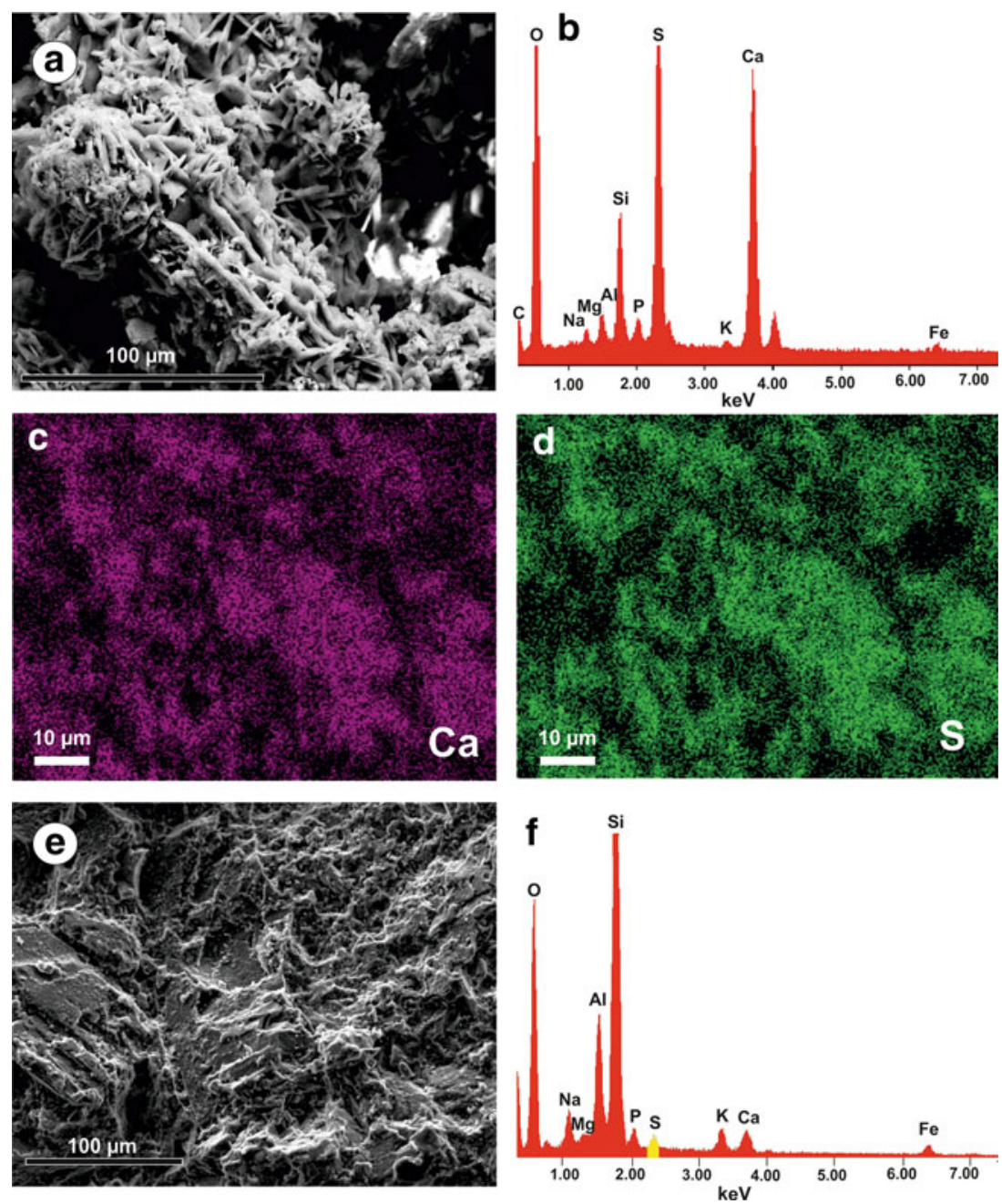

organic matter (black opaque particles). The crust formation on the Drachenfels trachyte is characterized by a thin, dense black layer on the surface of the host rock (10-20 $\mu \mathrm{m})$ mainly consisting of organic material or carbonaceous particles (containing elemental and organic carbon) (Saiz-Jimenez 1993; Turpin and Huntzicker 1995), which may function as catalyst for the formation of gypsum (Amoroso and Fassina 1983; Rodriguez-Navarro and Sebastian 1996; Ausset et al. 1992). On this surface layer, a porous framboidal crust builds with finely distributed gypsum crystals and crystal aggregates together with quartz and feldspar particles $(<0.1 \mathrm{~mm})$ (Fig. 7d). The brownish tanning derives from iron-oxides/hydroxides (Do 2000). Framboidal black crusts on Drachenfels trachyte can be described as a porous mixture of gypsum, organic compounds, iron oxides, quartz, and feldspar particles. A large number of siliceous as well as carbonaceous fly ash particles are commonly embedded in such crusts and high ratios of Fe-rich particles are detected. In the limestone samples, the fly ash particles are firmly incorporated into the gypsum crust, surrounded by gypsum crystals and overgrown with sub-micron size gypsum crystals (Török et al. 2011). However, although fly ash particles are found embedded in the trachyte structure in the samples of Drachenfels trachyte, their incorporation into the crust is not as strongly wedded to the growth of gypsum crystals as is the case in the crust on limestone. SEM-EDX analyses of the crust surface reveal a high gypsum concentration for framboidal crusts (Fig. 8a-d), whereas on laminar crusts a composition mainly of silicate and organic components is detected (Fig. 8e-f). The thin opaque black layer on the surface of the host rock marks the boundary of the stone, on which the crust forms. In some places, this defined line is distorted, which may be attributed to the structural disintegration of the stone material underneath. Surface parallel cracks are often observed in the host rock beneath the crust. These cracks not only run along grain boundaries, but also characteristically cut through larger grains and minerals (Fig. 7d). This structural degradation of the host rock finally leads to the detachment of the crust including the upper superficial region of the host rock. The width of this detached zone is not limited to the crust but reaches into 
Table 2 Main element composition of samples (data set of XRF analyses in wt. \%)

\begin{tabular}{|c|c|c|c|c|c|c|c|c|c|c|c|c|c|c|c|}
\hline Sample & No. sample & $\mathrm{SiO}_{2}$ & $\mathrm{TiO}_{2}$ & $\mathrm{Al}_{2} \mathrm{O}_{3}$ & $\mathrm{Fe}_{2} \mathrm{O}_{3}$ & $\mathrm{MnO}$ & $\mathrm{MgO}$ & $\mathrm{CaO}$ & $\mathrm{Na}_{2} \mathrm{O}$ & $\mathrm{K}_{2} \mathrm{O}$ & $\mathrm{P}_{2} \mathrm{O}_{5}$ & $\mathrm{H}_{2} \mathrm{O}$ & $\mathrm{CO}_{2}$ & $\mathrm{SO}_{3}$ & $\sum$ \\
\hline Host rock & $n=5$ & 64.31 & 0.72 & 16.97 & 3.49 & 0.11 & 0.85 & 2.43 & 4.56 & 5.22 & 0.18 & 0.92 & 0.22 & 0.04 & 99.9 \\
\hline Altenberg & $n=3$ & 63.17 & 0.77 & 16.68 & 3.92 & 0.09 & 0.63 & 2.41 & 4.58 & 4.69 & 0.19 & 1.56 & 1.21 & 0.30 & 100.2 \\
\hline Cologne & $n=10$ & 54.45 & 0.65 & 13.79 & 3.86 & 0.09 & 0.68 & 6.72 & 3.71 & 4.05 & 0.51 & 0.92 & 0.92 & 5.90 & 100.3 \\
\hline Xanten & $n=5$ & 59.80 & 0.71 & 15.12 & 4.06 & 0.14 & 0.74 & 4.24 & 4.24 & 4.39 & 0.22 & 0.99 & 0.54 & 2.77 & 99.8 \\
\hline
\end{tabular}

Table 3 Concentrations of sulfur (wt. \%) (calculated from $\mathrm{SO}_{4}{ }^{2-}$ content of soluble salts) detected in the black crusts on stone masonry from different urban sites in Europe

\begin{tabular}{llllll}
\hline S (wt. \%) & 13.8 & $14.6-23.3$ & $10.5-16.2$ & $10.3-13.4$ & $13.2-20.3$ \\
\hline $\begin{array}{l}\text { Investigated } \\
\text { sites }\end{array}$ & Rome, Italy & Venice, Italy & Northern and central Italy & Mediterranean coast & Eleusis, Greece \\
& $\begin{array}{c}\text { Brocco et al. } \\
(1988)\end{array}$ & Fassina & $\begin{array}{c}\text { Sabbioni and Zappia (1992a) and } \\
(1988)\end{array}$ & $\begin{array}{c}\text { Torfs and van Grieken } \\
(1997)\end{array}$ & $\begin{array}{c}\text { Moropoulou et al. } \\
(1998)\end{array}$ \\
\hline
\end{tabular}

the host rock with a thickness of 3-10 mm. The host rock shows further structural disintegration in the form of multiple flaking and exfoliation (Fig. 4).

Laminar crusts are very thin $(5-15 \mu \mathrm{m}$, where bulging occurs up to $50 \mu \mathrm{m}$ ) and have a dense composition of mainly organic compounds with parts of gypsum, iron oxides, quartz, and feldspar particles (Fig. 7c). As observed with framboidal crusts, the host rock beneath laminar crusts also shows surface parallel cracking with a lower quantity and latitude of the cracks. In context with laminar crusts, the structural disintegration of the stone is often manifested in the form of scales $0.5-1.5 \mathrm{~cm}$ thickness.

\section{Geochemical characterization}

The results of the XRF analyses show a significant relative depletion of $\mathrm{SiO}_{2}(2-15 \%)$ and of $\mathrm{Al}_{2} \mathrm{O}_{3}(2-19 \%)$ in the crust samples in respect to the host rock (Table 2). Also $\mathrm{K}_{2} \mathrm{O}$ shows an average decrease of $10-22 \%$ and $\mathrm{Na}_{2} \mathrm{O}$ of 0.5-19\%. The mean enrichment of $\mathrm{Fe}_{2} \mathrm{O}_{3}$ for the samples from Altenberg is $12 \%$, for the Xanten samples $16 \%$, and for the Cologne samples $11 \%$. The enormous increase of $\mathrm{P}_{2} \mathrm{O}_{5}$ concentration is striking, which is three times higher for the Cologne samples. An enrichment of $\mathrm{CaO}$ within the crust is clearly noticeable for the samples from Cologne (factor 2.8) and from Xanten (factor 1.7). The average $\mathrm{CaO}$-enrichment in the Altenberg samples is within the measurement accuracy. The increase in $\mathrm{SO}_{3}$, respectively, the sulfur concentration, shows a similar tendency: the Cologne samples shows an enrichment of sulfur with factor 139, the Xanten samples with factor 65, and the Altenberg samples with factor 7 . The depletion of the oxides associated with silicate phases $\left(\mathrm{SiO}_{2}, \mathrm{Al}_{2} \mathrm{O}_{3}, \mathrm{Na}_{2} \mathrm{O}, \mathrm{K}_{2} \mathrm{O}\right)$ correlates with the increase in $\mathrm{SO}_{3}$.
In crusts on limestone, where the substrate consists almost entirely of $\mathrm{CaCO}_{3}$, a depletion of $\mathrm{CaO}$ and an enrichment of $\mathrm{SiO}_{2}$ as well as aluminum and iron in the crust are detected (Török et al. 2011). The contrary is found for crusts on silicate stones: a relative depletion of oxides associated with silicate phases and an enrichment of $\mathrm{CaO}$ in the crust along with an enormous increase in sulfur, indicating high gypsum enrichment in the crust. The average sulfur concentrations normalized to the host rock correlate to gypsum contents for Altenberg (0.6 wt. \%), Xanten (5.9 wt. \%) and Cologne (12.6 wt. \%). The sulfur concentration found in crust samples on limestoneinvestigated by Török et al. (2011)_correlates to an average gypsum amount of 22 wt. \% in respect to the host rock. Gypsum concentrations in samples from marble and limestone from different sites range from 10.3 (Torfs and van Grieken 1997) to 23.3 wt. \% (Fassina 1988) (Table 3).

The data show a clear discrimination of framboidal and laminar crusts (Table 4). A stronger depletion for $\mathrm{SiO}_{2}$, $\mathrm{Al}_{2} \mathrm{O}_{3}$, and $\mathrm{Na}_{2} \mathrm{O}$ as well as for $\mathrm{K}_{2} \mathrm{O}$ is detectable. The increase of $\mathrm{CaO}$ and $\mathrm{SO}_{3}$ concentrations from laminar to framboidal crusts is significant.

The calculated content of gypsum in the analyzed samples of framboidal crusts from Cologne is about 60 wt. \%, and in the samples of framboidal crusts from Xanten about 29 wt. \%. However, the samples of laminar crusts show a quite similar low gypsum concentration for the three locations: Altenberg 0.55 wt. \%, Xanten 0.04 wt. \%, and Cologne 0.88 wt. $\%$. In terms of the mineralogical determination by the Rietveld method, the gypsum concentration of the laminar crust samples are below the detection limit for gypsum by XRD, but the framboidal crust samples clearly indicate gypsum content (Table 5; Fig. 9).

The enrichment of $\mathrm{CO}_{2}$ in the samples for Altenberg (factor 5.6), Cologne (factor 4.2) and Xanten (factor 2.5) 
Table 4 Enrichment factors of main elements in laminar and framboidal crust samples from Altenberg, Xanten, and Cologne relative to the host rock

\begin{tabular}{llllllllll}
\hline Sample & No. sample & $\mathrm{SiO}_{2}$ & $\mathrm{Al}_{2} \mathrm{O}_{3}$ & $\mathrm{Fe}_{2} \mathrm{O}_{3}$ & $\mathrm{CaO}$ & $\mathrm{Na}_{2} \mathrm{O}$ & $\mathrm{K}_{2} \mathrm{O}$ & $\mathrm{P}_{2} \mathrm{O}_{5}$ & $\mathrm{SO}_{3}$ \\
\hline Laminar crusts & & & & & & & & \\
Altenberg & 3 & 0.98 & 0.98 & 1.12 & 0.99 & 1.01 & 0.90 & 1.05 & 7.05 \\
Xanten & 5 & 0.99 & 0.96 & 1.19 & 1.03 & 1.02 & 0.90 & 1.25 & 1.41 \\
Cologne & 8 & 0.98 & 0.95 & 1.18 & 1.38 & 0.98 & 0.90 & 1.21 & 10.57 \\
Framboidal crusts & & & & & & & & \\
Xanten & 1 & 0.71 & 0.66 & 1.02 & 4.46 & 0.61 & 0.63 & 1.05 & 319.6 \\
Cologne & 2 & 0.33 & 0.27 & 0.81 & 8.33 & 0.16 & 0.29 & 9.55 & 651.8 \\
\hline
\end{tabular}

Table 5 Main mineral phases of black crust and host rock (xxx: major, $\mathrm{xx}$ : medium, $\mathrm{x}$ : minor) (see sample description in Table in "Appendix")

\begin{tabular}{llllllll}
\hline Sample code & Cathedral & Quartz & Sanidine & Plagioclase & Pyroxen & Biotite & Gypsum \\
\hline DT-03 & - & $\mathbf{x}$ & $\mathbf{x x x}$ & $\mathbf{x x x}$ & $\mathbf{x}$ & $\mathrm{x}$ & \\
AL-02 & Altenberg & $\mathbf{x x}$ & $\mathbf{x x x}$ & $\mathbf{x x x}$ & $\mathbf{x x}$ & $\mathbf{x}$ & \\
AL-03 & Altenberg & $\mathbf{x x}$ & $\mathbf{x x x}$ & $\mathbf{x x x}$ & $\mathbf{x}$ & $\mathbf{x}$ & \\
CL-06 & Cologne & $\mathbf{x x}$ & $\mathbf{x x x}$ & $\mathbf{x x x}$ & $\mathbf{x}$ & $\mathbf{x}$ & \\
CL-08 & Cologne & $\mathbf{x x}$ & $\mathbf{x x x}$ & $\mathbf{x x x}$ & $\mathbf{x}$ & $\mathbf{x}$ & \\
CL-07 & Cologne & $\mathbf{x x}$ & $\mathbf{x x x}$ & $\mathbf{x x x}$ & $\mathbf{x}$ & $\mathbf{x}$ & \\
CF-09 & Cologne & $\mathrm{x}$ & $\mathbf{x x x}$ & $\mathbf{x x x}$ & $\mathrm{x}$ & $\mathrm{x}$ & $\mathrm{x}$ \\
XF-06 & Xanten & $\mathrm{x}$ & $\mathbf{x x x}$ & $\mathbf{x x x}$ & $\mathrm{x}$ & & $\mathrm{x}$ \\
XL-05 & Xanten & $\mathbf{x}$ & $\mathbf{x x x}$ & $\mathbf{x x x}$ & $\mathbf{x x}$ & $\mathbf{x}$ & \\
\hline
\end{tabular}

(Table 2) indicates a certain amount of carbonaceous fly ash particles in the investigated material as well as a partition of organic material, especially for the investigated samples from Altenberg. This again illustrates the importance of settling dust and particles in terms of weathering crust formation.

\section{Microscale chemical investigation}

Laser ablation inductively coupled plasma mass spectrometry analyses show clear trends in terms of major and trace element distribution in the black crusts and the host rock. The microscale chemical investigation also reveals little change in oxides associated with the silicate phases. An enrichment of sulfur, lead, antimony, bismuth, and arsenic in black weathering crusts developed on Drachenfels trachyte is detected (Fig. 10). The crusts of the Cologne cathedral show an average concentration of $1,849 \mathrm{ppm} \mathrm{Pb}$, those of Xanten $1,944 \mathrm{ppm} \mathrm{Pb}$, while the crusts of Altenberg only show $890 \mathrm{ppm} \mathrm{Pb}$-which corresponds to enrichment factors of 105, 110, and 50 in respect to the host rock (Table 6; Fig. 10).

The samples from the three locations are clearly distinguishable. Comparing industrial, urban and rural samples, data show high concentrations of heavy metals (e.g., $\mathrm{Pb}$ and $\mathrm{Bi}$ ), As and $\mathrm{Si}$ in black crust samples collected from the industrial and urban sites (Cologne and Xanten). The samples from the rural area (Altenberg) contain significantly lower concentrations of heavy metals (Table 6). This clearly indicates a very strong pollution impact for the Cologne and Xanten samples, since the content of these elements is due to an intense impact of combustion emissions (Fig. 11).

In view of decreasing $\mathrm{SO}_{2}$ fluxes, the ban on leaded petrol, and emission regulations, the high concentrations of heavy metals as anthropogenic combustion tracers in the samples from Cologne result not only from recent air pollution but show the long history of industrial development at this location. The high lead concentrations in the Xanten samples can be traced back to the strong impact of the industrial area of Arnhem (NL) over a long period of time.

The weathering crusts show high enrichment of the detected elements, whereas within the first $100-300 \mu \mathrm{m}$ of the surface of the host rock a general decrease is detectable (Fig. 10). An accumulation can be observed in cracks and small cavities of the host rock (Fig. 10). This correlates well with the phenomenon observed by Török et al. (2011), that in the porous zone below the crust, an increase of $\mathrm{Pb}$ is observed, which marks the accumulation of lead not only within the crust but in the pores, too. The enrichment in the cracks demonstrates, that pollutants are not only superficially fixed to the crust, but also penetrate deeper into the stone and accumulate in structurally altered zones.

The plots of the $\mathrm{S} / \mathrm{Si}, \mathrm{Ca} / \mathrm{Si}$, and $\mathrm{Pb} / \mathrm{Si}$ ratios show a sharp increase in the crust, indicating a high enrichment of $\mathrm{Pb}$ and $\mathrm{S}$ as well as of $\mathrm{Ca}$ in the crust (Fig. 10). The major 
Fig. $9 \mathrm{CaO}$ versus $\mathrm{SO}_{3}$ content indicates the part of gypsum at the sample. The higher the amount of $\mathrm{SO}_{3}$, the higher the gypsum content of the sample. The molar ratio of calcium versus sulfur in gypsum $\left(\mathrm{CaSO}_{4} \cdot \mathrm{H}_{2} \mathrm{O}\right)$ is $1: 1$ (black line). The samples are above this molar ratio $\left(\mathrm{Ca} / \mathrm{S}\right.$ or $\mathrm{CaO} / \mathrm{SO}_{3}$, respectively), suggesting that the total of sulfur in the samples is present as gypsum. The $\mathrm{CaO}$ content can be assigned to gypsum as well as to the rockforming minerals (e.g., plagioclases). An enrichment of calcite $\left(\mathrm{CaCO}_{3}\right)$ cannot be correlated (see also Table 5)

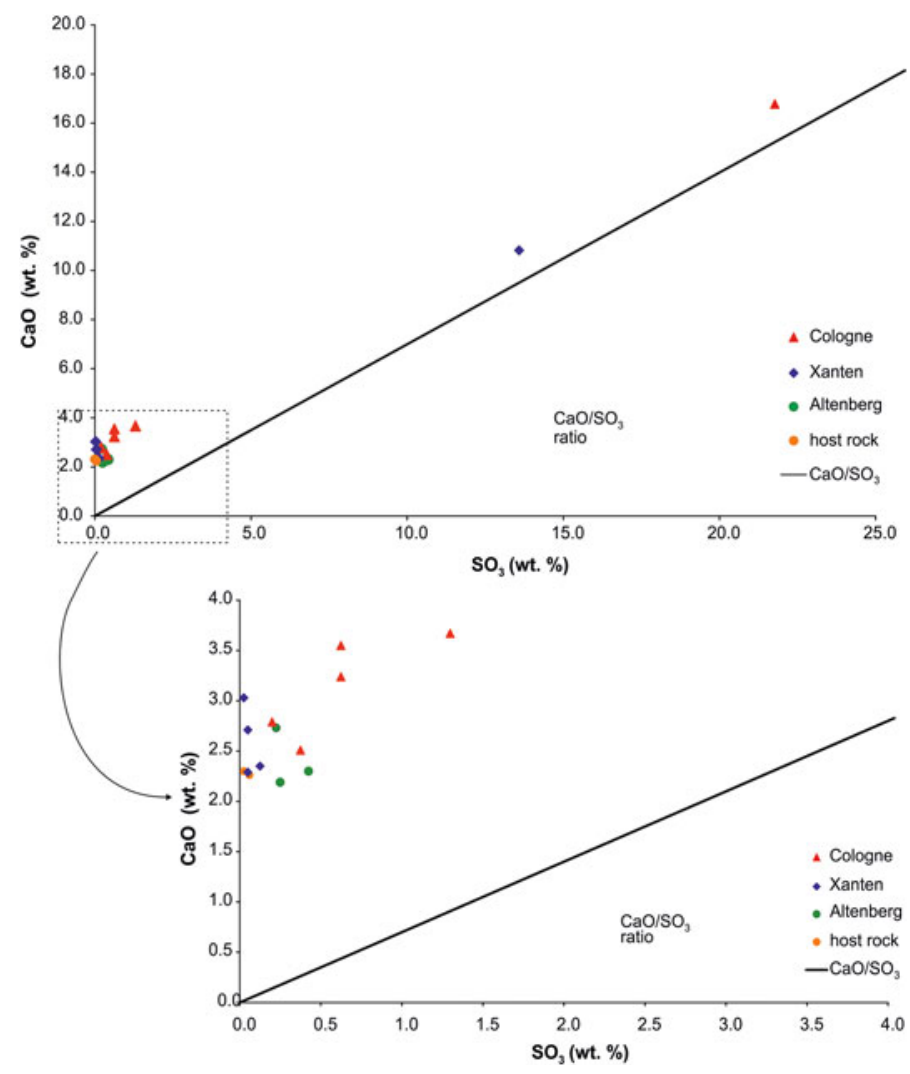

the host rock. The range of the detected $21 \mathrm{PAH}$ compounds are from acenaphthylene (m/z 152) to dibenzo(ah)pyrene (m/z 302).

The total concentrations of the PAH compounds varies from 62 (laminar crust from Xanten cathedral) to $13,525 \mu \mathrm{g} / \mathrm{kg}$ OS (dust sample from Cologne cathedral) (Table 8). The high-end values belong to samples from Cologne cathedral and are typical for samples from an industrial area. The PAH concentrations of the samples from Xanten and Altenberg are in a close range (Table 8). A clear relationship can be drawn between PAH concentration and sample type. If the Cologne samples are compared to each other, samples of dust, framboidal weathering crusts, and strongly deteriorated stone material (scale and disaggregated stone) generally show higher PAH concentrations $(1,362-13,525 \mu \mathrm{g} / \mathrm{kg}$ OS); samples of laminar crusts and slightly weathered stone show lower values (247-482 $\mu \mathrm{g} / \mathrm{kg}$ OS).

When data from Török et al. (2011) are included, the higher PAH concentrations are in dust samples and from framboidal crusts from Cologne, Budapest, and Halle (Fig. 12; red ellipse). This group of samples also shows high $\mathrm{SO}_{4}{ }^{2-}$ concentrations. A second group of low $\mathrm{PAH}$ but higher $\mathrm{SO}_{4}{ }^{2-}$ concentrations (Fig. 12; black ellipse) contains mainly laminar crusts from rural areas in Hungary as well as from Xanten and Altenberg besides four samples 
Fig. 10 LA-ICP-MS analyses along a profile perpendicular to the surface on a thin cut of a black weathering crust (Drachenfels trachyte; Cologne cathedral). a Concentration profiles of $\mathrm{S}, \mathrm{Pb}, \mathrm{Sb}, \mathrm{Bi}$, and $\mathrm{As}$; b microscopic picture of the ablated line; c S/Si, $\mathrm{Ca} / \mathrm{Si}$, and $\mathrm{Pb} / \mathrm{Si}$ ratios (and normalized $\mathrm{Si}$ content) plotted against the length of the line

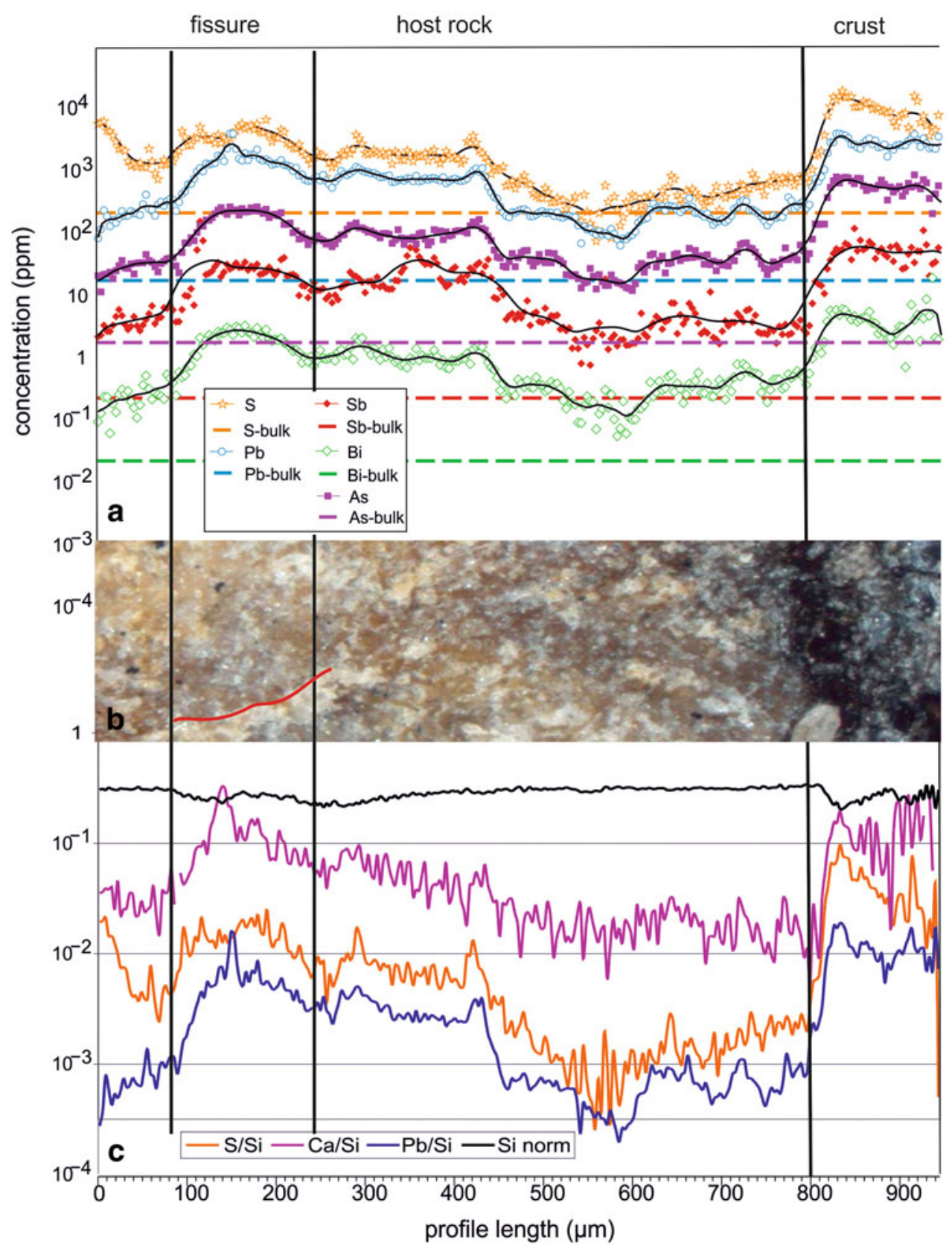

Table 6 Mean values for $\mathrm{S}, \mathrm{Ca}, \mathrm{Pb}, \mathrm{Sb}, \mathrm{Bi}$, and $\mathrm{As}$ in the host rock and in the crust from the Altenberg, Cologne, and Xanten samples

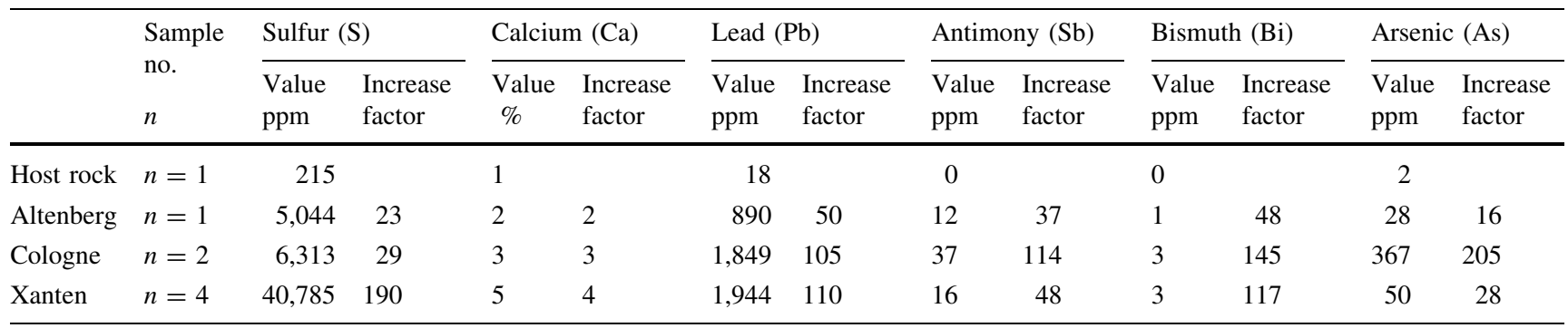

from Hungarian host rock. Except for one sample from Xanten (Drachenfels trachyte), these crust and host rock samples derive from limestone. A third group is formed by deterioration samples from Cologne cathedral on Drachenfels trachyte (Fig. 12; green ellipse). These samples show certain enrichment in $\mathrm{SO}_{4}{ }^{2-}$, but a stronger 

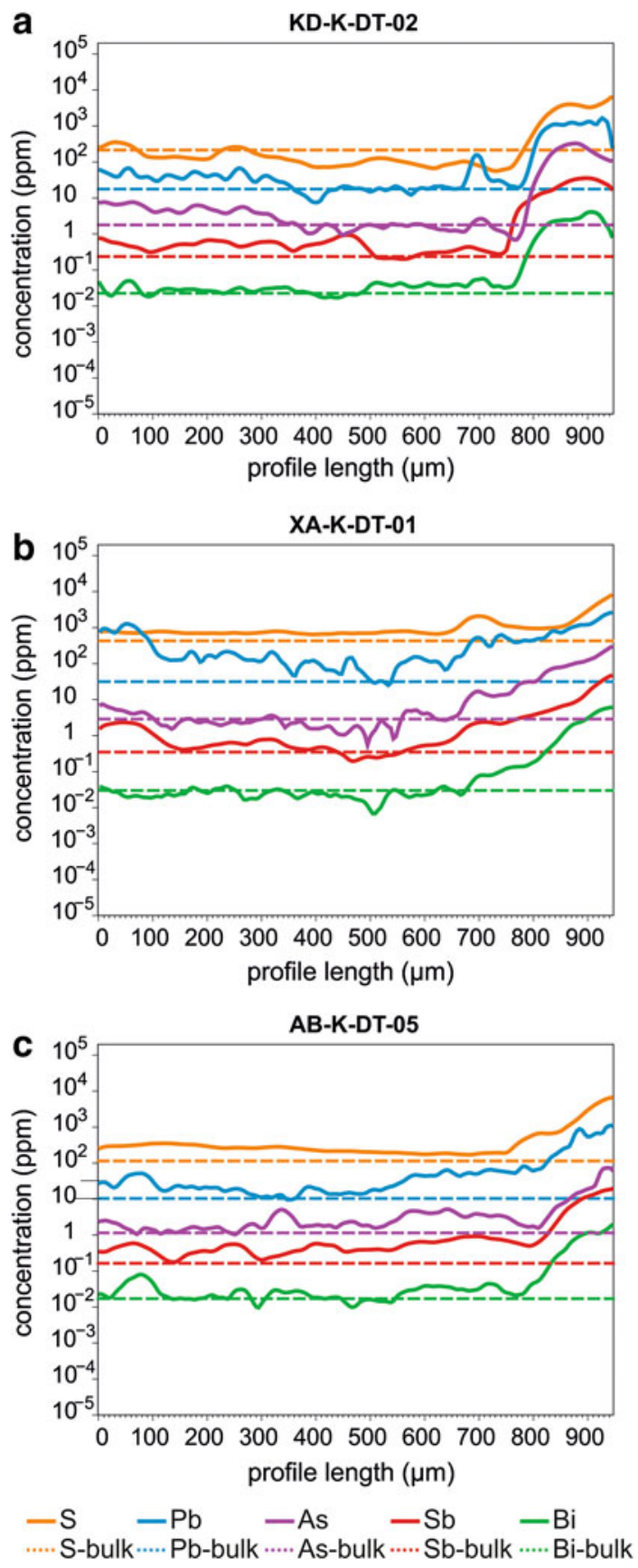

Fig. 11 Distribution of sulfur $(\mathrm{S})$, lead $(\mathrm{Pb})$, antimony $(\mathrm{Sb})$, bismuth (Bi), and arsenic (As) in black weathering crusts developed on Drachenfels trachyte normalized to earth crust values (blk) in a Altenberg, b Cologne, and c Xanten. LA-ICP-MS analyses, perpendicular to the sample surface (concentrations are in $\mathrm{ppm}$ ), showing an enrichment of $\mathrm{S}, \mathrm{Pb}, \mathrm{Sb}, \mathrm{Bi}$, As in the crust

increase of PAH. A fourth group with low $\mathrm{SO}_{4}{ }^{2-}$ and moderate PAH concentrations (Fig. 12; blue ellipse) contains a host rock sample of the Drachenfels trachyte, and further consists of samples of light weathered stone and of laminar crusts from Cologne, Altenberg and, Naumburg as well as rural areas in Hungary.
Table 7 Concentrations (ppm) of lead $(\mathrm{Pb})$ detected in the black crusts on stone masonry from different urban sites in Europe

\begin{tabular}{lll}
\hline Location & $\begin{array}{l}\text { Lead }(\mathrm{Pb}) \\
(\mathrm{ppm})\end{array}$ & Stone substrate \\
\hline Cologne & 1,849 & Trachyte \\
Xanten & 1,944 & Trachyte \\
Halle, GER* & 2,000 & Limestone \\
Budapest* $^{*}$ & 1,000 & Limestone \\
Milan $^{\circ}$ & 883 & Marble and limestone \\
Venice $^{\circ}$ & 123 & Marble and limestone \\
Rome $^{\circ}$ & 532 & Marble and limestone \\
Bologna $^{\circ}$ & 427 & Marble and limestone \\
Eleusis $^{\circ}$ & 300 & Marble and limestone \\
Brussels $^{\circ}$ & 516 & Sandstone and calcarenite \\
Bologna $^{\circ}$ & 160 & Sandstone and calcarenite \\
Granada $^{\circ}$ & 40 & Sandstone and calcarenite \\
\hline
\end{tabular}

* (Török et al. 2011; ${ }^{\circ}$ after Sabbioni 2003)

\section{Discussion}

Crust formation on Drachenfels trachyte in comparison to limestone

As the investigations and mapping show, gypsum crusts not only build on calcareous stones, but also on silicate stones. In comparison to black weathering crusts on limestone, the crusts on the silicate Drachenfels trachyte are lower in gypsum content $(223 \mathrm{~g} / \mathrm{kg}$ on average on limestone, $126 \mathrm{~g} / \mathrm{kg}$ on average on Drachenfels trachyte; relative to the corresponding host rock). Also framboidal crusts are less frequent than laminar crusts on Drachenfels trachyte than on limestone. This is easily explained by the calcium source for the gypsum. The limestone displays a vast source of calcium ions for the formation of gypsum crusts, as a matter of transformation from $\mathrm{CaCO}_{3}$ into $\mathrm{CaSO}_{4}$. The Drachenfels trachyte, however has an original concentration of 2.43 wt. \% $\mathrm{CaO}$, which is mainly contained in silicate minerals and is not easily available for the formation of gypsum.

For crusts on limestone, a significant difference in chemical composition between host rock and crust is reported (Török et al. 2011). This is not the case for black weathering crusts on Drachenfels trachyte, where the crusts show a similar chemical composition to the host rock with a depletion of oxides associated with silicate phases and enrichment in $\mathrm{Ca}$ and $\mathrm{S}$. The morphology and composition of the crusts' surfaces on limestone and on silicate trachyte differ significantly. Török et al. (2011) found a surface composition of primarily gypsum crystals as well as calcite. They found idiomorphic rosette-like gypsum crystals in samples from industrial environments and slightly 




Fig. $12 \mathrm{PAH}$ versus $\mathrm{SO}_{4}{ }^{2-}$ concentrations of studied samples. The data set shows distinct fields with different origin of samples, indicating the difference in composition of dust, black weathering crusts, and host rock

Table $8 \mathrm{PAH}$ and $\mathrm{SO}_{4}{ }^{2-}$ concentrations of samples from Altenberg, Cologne, and Xanten, as well as Hungary and the city centers of Budapest and Halle

\begin{tabular}{|c|c|c|c|c|}
\hline Sample code & Stone & Description & PAH total $\mu \mathrm{g} / \mathrm{kg}$ OS & $\mathrm{SO}_{4} \mathrm{mg} / \mathrm{kg}$ \\
\hline DT-01 & Drachenfels trachyte & Host rock & 179.12 & 299.92 \\
\hline AL-02 & Drachenfels trachyte & Laminar crust & 82.11 & $5,092.30$ \\
\hline AL-03 & Drachenfels trachyte & Laminar crust & 669.13 & $2,995.47$ \\
\hline AF-04 & Krensheimer Muschelkalk & Framboidal crust & 226.89 & $43,364.10$ \\
\hline CL-06 & Drachenfels trachyte & Laminar crust & 481.54 & $1,497.74$ \\
\hline CL-07 & Drachenfels trachyte & Laminar crust & $3,872.46$ & $3,295.02$ \\
\hline CD-07 & Drachenfels trachyte & Disaggregated material behind scale & $5,121.95$ & $6,590.04$ \\
\hline CL-08 & Drachenfels trachyte & Laminar crust & 246.65 & 898.64 \\
\hline CD-08 & Drachenfels trachyte & Disaggregated material behind scale & $1,362.24$ & $6,290.49$ \\
\hline CF-11 & Krensheimer Muschelkalk & Host rock & $5,004.50$ & $165,368.64$ \\
\hline CS-01 & Obernkirchner Sandstein & Dust surface deposition & $13,525.07$ & \\
\hline XL-05 & Drachenfels trachyte & Laminar crust & 420.47 & 599.09 \\
\hline XL-07 & Drachenfels trachyte & Laminar crust & 62.25 & $33,549.29$ \\
\hline
\end{tabular}

dissolved gypsum crystals commonly associated with calcite in samples from rural places in Hungary and Germany. The crusts on the silicate trachyte showed higher contents of siliceous compounds and organic matter and smaller content of gypsum compared to crusts on limestone. At Cologne cathedral, the crust formation on limestone shows a very dense crust without any transitional zone, whereas the black crusts on the Drachenfels trachyte are a very porous poly-mineral composition with heterogeneous particle size.
Sulfur and calcium sources

The crust samples on Drachenfels trachyte have a higher sulfur as well as higher calcium content in correlation to the fresh stone (enrichment factor for S: 7-139; enrichment factor for $\mathrm{Ca}: 1-3)$. The chemical analyses reveal very low calcium $(1.74$ wt. \%) and sulfur $(<0.02$ wt. \%) concentration in the Drachenfels trachyte (Table 2). This indicates that for sulfur and calcium, external sources are responsible for the crust formation. Lefèvre et al. (1998) report on 

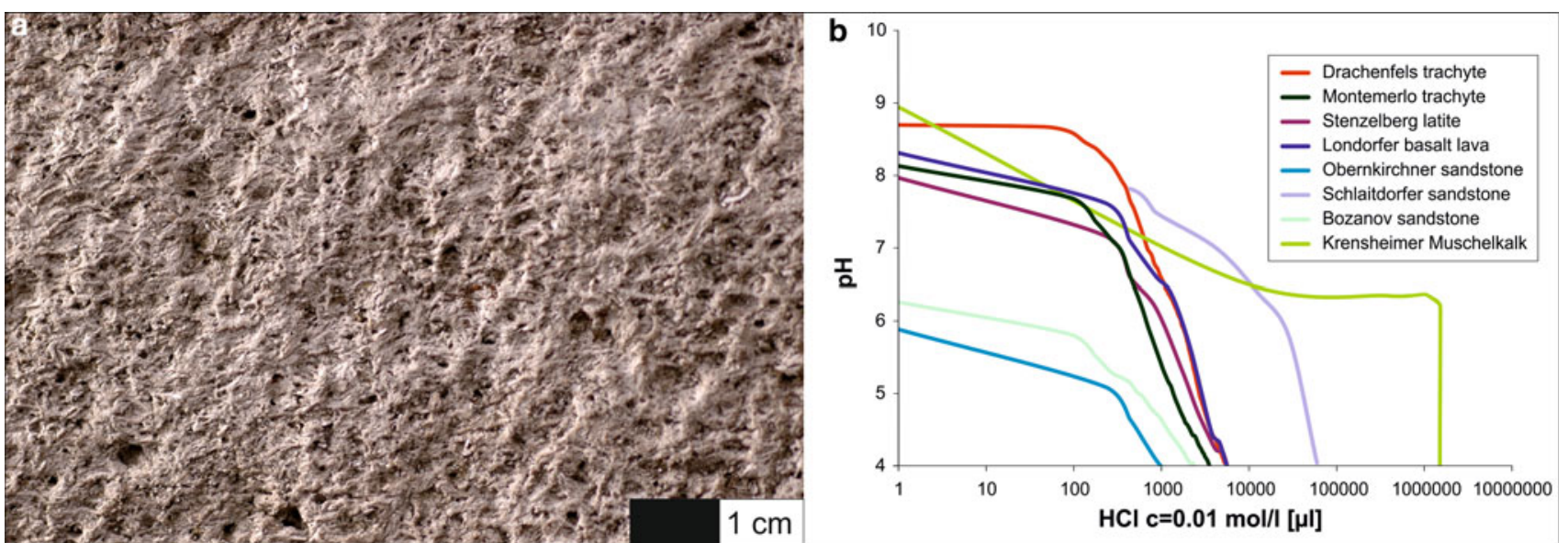

Fig. 13 a Weathered surface of Krensheimer Muschelkalk showing surface roughness; $\mathbf{b}$ tests on the acid binding capacity showing the extent of material solution

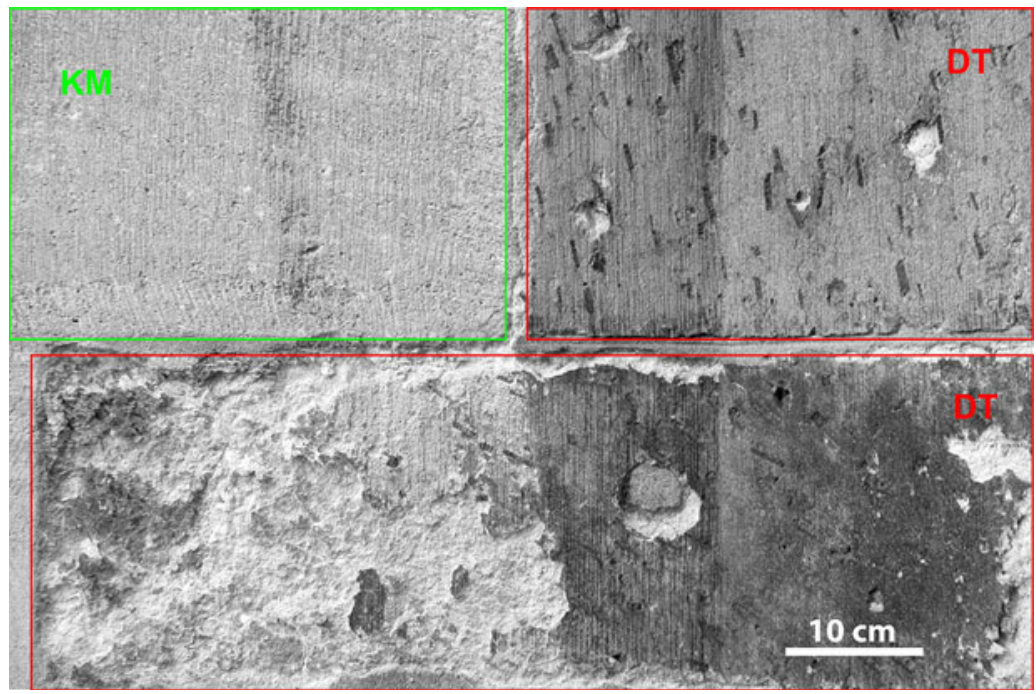

Fig. 14 Wall section at Cologne cathedral. Upper left stone: Krensheimer Muschelkalk (KM); upper right and lower layer stones: Drachenfels trachyte (DT). The left side of the lower Drachenfels trachyte is in the flow direction of ion-loaded water from the limestone, which enhances the crust formation and decay. Also, a

gypsum crusts on stained glass windows in areas sheltered from rain. This again underlines the major impact of external calcium and sulfur sources.

Sulfur derives from anthropogenic pollution impact and imports via wet and dry deposition. The most important sulfur sources are $\mathrm{SO}_{2}$ deposition from air and $\mathrm{SO}_{4}{ }^{2-}$ from rainwater (Neumann et al. 1993). Torfs and Van Grieken (1997) mention that gypsum formation is more likely related to $\mathrm{SO}_{2}$, which is the airborne sulfur, indicating the major impact of dust and dry deposition. This correlates to the investigation by Furlan and Girardet (1983), who state that, especially in highly polluted areas, the impact of dry deposition is far more important than wet deposition as a source of building stone decay. Laboratory analyses of stronger deterioration of the Drachenfels trachyte is observed close to the joints, where alkaline leaching products of the mortar might have a certain impact. The massive surface deterioration on the left side of the lower layered Drachenfels trachyte correlates with the coverage of the top Krensheimer Muschelkalk

sulfate-rich fog water confirmed that $60 \mathrm{~h}$ after a main fog event, gypsum crystals were formed (Del Monte and Rossi 1997). This indicates that the $\mathrm{SO}_{4}{ }^{2-}$ import from rainwater and fog as well as the dry deposition of $\mathrm{SO}_{2}$ in the context of corresponding humidity (e.g., fog, condensation) function as sulfur sources for the gypsum formation.

The calcium import comes from aerosol deposition and leaching products from mortars (e.g., joint mortar) (Snethlage and Wendler 1997; Kraus 1980; Hughes et al. 1998) as well as from adjacent calcareous stones.

The role of particulate matter in the form of dry and wet deposition and their contribution to the formation of black weathering crusts has already been discussed (Amoroso and Fassina 1983; Bonazza et al. 2004, 2005; Del Monte and 


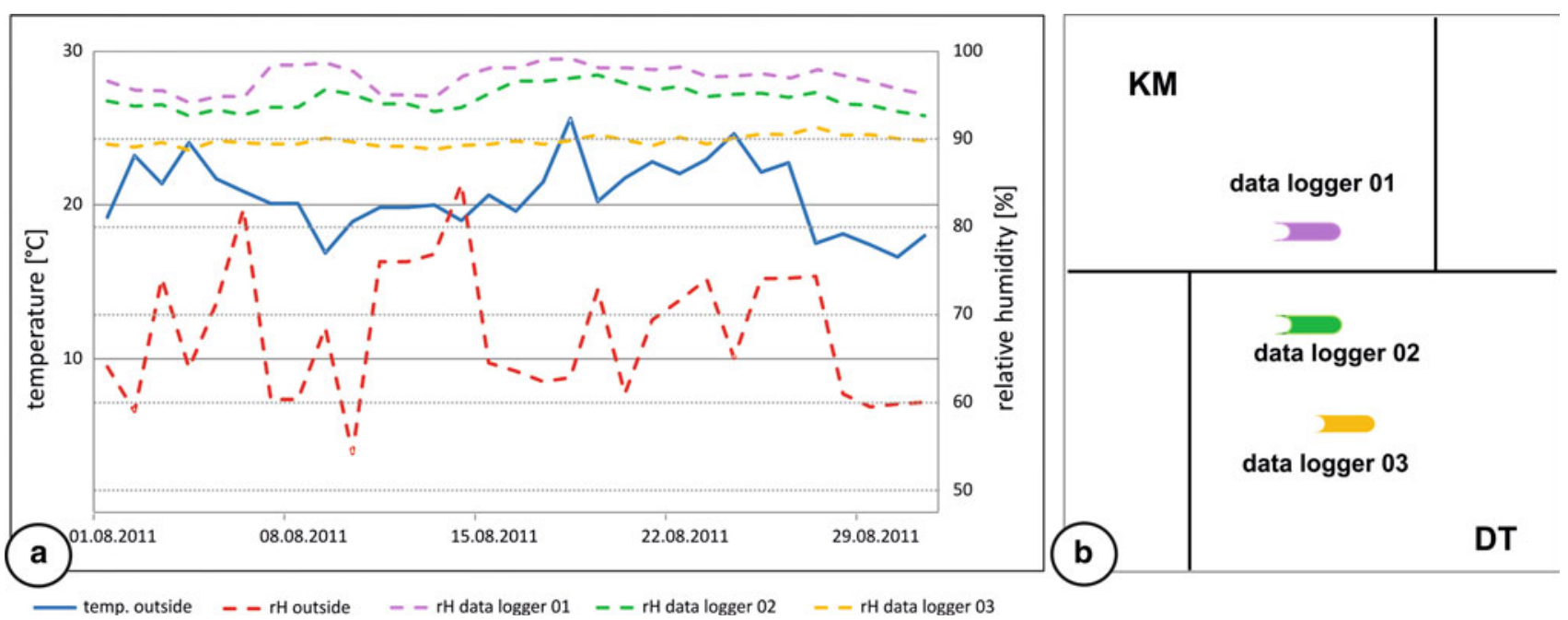

Fig. 15 a In situ measurements of temperature and relative humidity $(\mathrm{rH})$ at Cologne cathedral, August 2011: outside temperature (blue), outside $\mathrm{rH}(r e d)$, data logger $1 \mathrm{rH}$ (purple), data logger $2 \mathrm{rH}$ (green), data logger $3 \mathrm{rH}$ (yellow). b Scheme of sensors: data logger 1 is

Vittori 1985; Del Monte et al. 2001; Fassina et al. 2002; Lefèvre and Ausset 2002; Moropoulou et al. 1998; Smith et al. 1988; Trudgill et al. 2001; Viles 1994; Thornbush and Viles 2004). The dry deposition of airborne particles also includes calcium-rich aerosols, which therefore play their part in calcium import (Charola and Ware 2002). The total suspended particulate (TSP) matter is to be differentiated into PM10 and PM2.5 not only based on size, but also to differences in source, amount of emission, and physical and chemical behavior (Kainka et al. 1997). The composition of PM10 is generally dominated by large soot agglomerates, particles from tire abrasion and geogenic clay minerals and silica particles. In industrial areas, it may also contain slag, xenomorphic silica, salts, and gypsum and metallic particles. The coarse PM10 fraction from clean air regions contains particles mostly of biogenic and geogenic origin, but also clay minerals and quartz. Typical components from combustion are soot conglomerates (sometimes with balllike morphology) charcoal, fly ash particles of different sizes, xenomorphic silicates, and sulfates including gypsum. The finer PM2.5 fraction contains single soot particles or small soot agglomerates and fly ash particles (small balls). The latter are amorphous silica material with a high content of heavy metals. The fine PM2.5 fraction from clean air regions contains silicates and a few soot particles. The amount of PM2.5 can be smaller than PM10 in clean air regions. Geogenic particles, e.g., silicates, derive from mechanical abrasion and are found mostly in coarse fractions (PM10). The particulate air pollution caused by traffic is highly concentrated in the fine fraction (PM2.5), which is detected in all areas, and also in clean air regions (Kainka et al. 1997). Thus, in industrialized areas generally higher placed in the Krensheimer Muschelkalk (KM), data logger 2 is placed in the Drachenfels trachyte (DT) with little distance to Krensheimer Muschelkalk (KM) and the joint, data logger 3 is placed centered in the Drachenfels trachyte (DT)

PM concentrations are measured with high contents of soot, charcoal, and particles from tire abrasion as well as slag, and salts, e.g., gypsum and metallic particles. In general, a higher ratio of particulate air pollution is found, which is caused by traffic and contains large amounts of heavy metals. In clean air regions, however, particulate matter is dominated by biogenic and geogenic components as well as clay minerals, silicates, e.g., quartz, and a few soot particles, with an overall lower ratio of particulate air pollution caused by traffic.

Calcareous and sulfur compounds are constituents of weathering crusts and they participate in their formation in different ways. Dust and soot particles-especially when containing hygroscopic salts-can serve as condensation nuclei for droplets and thus provide sufficient moisture for further reactions (Charola and Ware 2002; Moroni and Poli 2000). Higher content of metallic compounds in the PM of industrial environments and higher concentration of carbonaceous particles enhance the $\mathrm{SO}_{4}{ }^{2-}$ formation on stone surfaces (Charola and Ware 2002; Zappia et al. 1998). Metals are mentioned to act as catalysts for the oxidation of $\mathrm{SO}_{2}$ into $\mathrm{SO}_{4}{ }^{2-}$. Soot particles containing heavy metals and metallic components of the particulate matter, e.g., abrasion material from tires, may function as reaction catalysts for the formation of calcium sulfate dihydrate, thus contributing to gypsum crust formation and stone decay. The experimental studies by Zappia et al. (1998) indicate two different reaction mechanisms for the formation of calcium sulfate dihydrate: an intermediate state of hemihydrate calcium sulfite or a direct formation of calcium sulfate dihydrate. The latter is linked to the presence of efficient catalysts, e.g., metallic compounds and strong oxidants. 

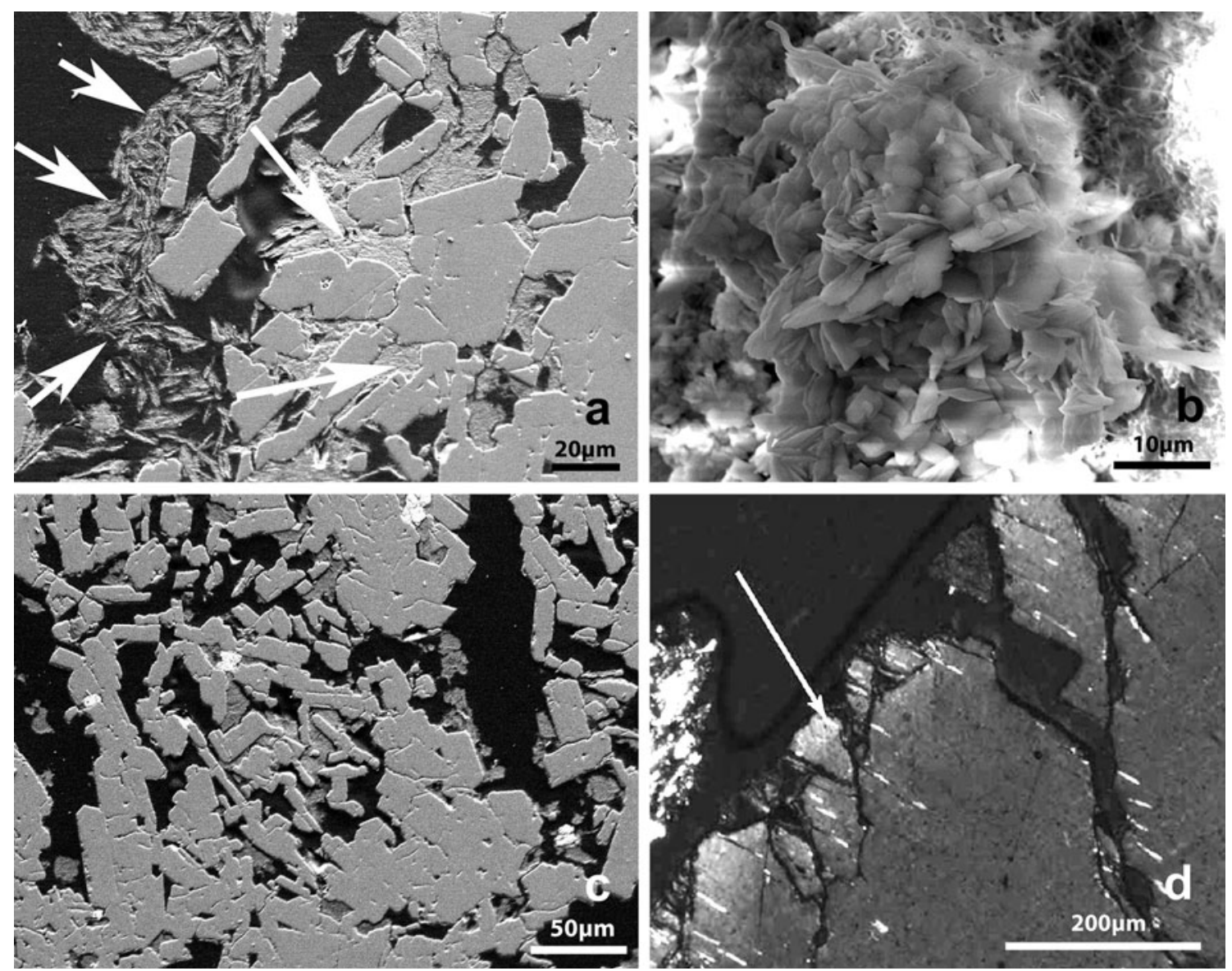

Fig. 16 a Gypsum (marked by arrows) is enriched in the crust as well as in the cracks (SEM); b rosette-shaped gypsum crystals on the reverse of a scale (SEM); c structurally disturbed zones, where no

Even though $\mathrm{SO}_{2}$ concentrations have been higher in the past and their effect on rock weathering might have been more significant than today, the $\mathrm{SO}_{2}$ concentrations today still have an effect on the stone deterioration, especially in the context of increasing particulate matter. The $\mathrm{NO}_{x}$ concentration of the air pollution plays a specific role. On the one hand, $\mathrm{NO}_{2}$ can function as an oxidant and increase the reaction rates of the sulfation processes significantly (Johansson et al. 1988). On the other hand, $\mathrm{NO}_{x}$ gases can be oxidized by lithotrophic bacteria to nitric acid, thus contributing to stone decay (Fuchs 2006).

The different incorporation of particulates, e.g., fly ash particles, into the gypsum crusts on limestone or on Drachenfels trachyte clearly indicates a very different formation process of the black weathering crusts. The limestone itself delivers the calcium component for the transformation of calcite into gypsum as an intense crystal growth takes place, where extrinsic particles, e.g., fly ash particles, are firmly incorporated. On the Drachenfels trachyte, a siliceous rock, calcium components are transported from external sources, as are other particles, e.g., fly ash gypsum is detected, indicating corrosion of feldspar grains (SEM); d fine-grained birefringent secondary minerals (marked by arrow) formed along the cleavage planes of sanidine phenocryst

particles. As the crust builds, it forms as a more or less loose and porous mixture of the different particles delivered by the pollution fluxes.

Already Grün (1931) considered the mortars used as a potential source for the deterioration. Wolff (1972) addressed the formation of gypsum crusts on Obernkirchner sandstone-sandstone with very little calcium content-to leaching alkaline components of the joint mortars. Mortars with latently hydraulic binders, e.g., puzzolana and diatomaceous earth, or cement components are commonly known for their capability to release water-soluble forms of sodium, potassium, calcium, and magnesium components (Arnold 1981, 1992; Bläuer-Böhm 2005; Kraus 2002; Kraus and Droll 2009; Schwiete et al. 1965). At Cologne cathedral, it can be observed that in many places the decay on the Drachenfels trachyte starts from the joints, which is indicated by gypsum crusts, flaking and scaling (Graue et al. 2011).

Besides alkaline mortars, neighboring calcareous stones, especially limestone, are also considered as a possibly contributing calcium source. As surface roughness 

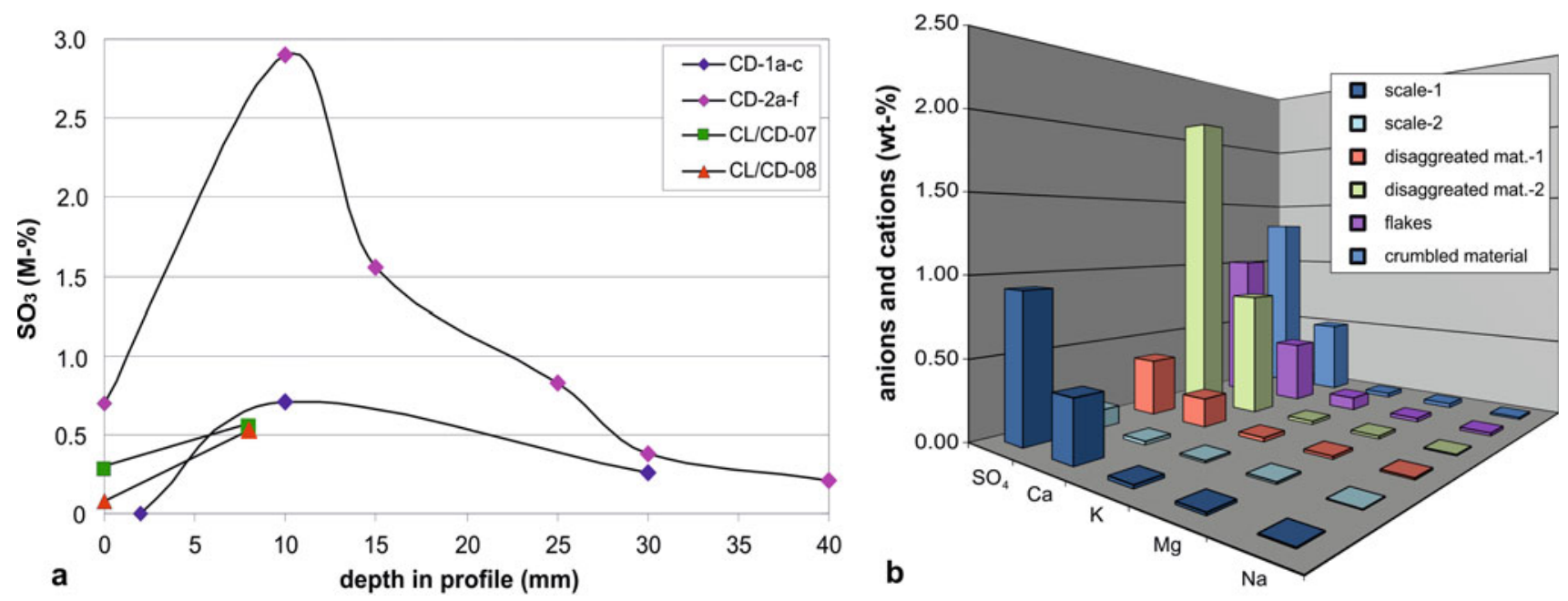

Fig. 17 a $\mathrm{SO}_{3}$ distribution in a depth profile of Drachenfels trachyte ( $\mathrm{SO}_{3}$ concentrations of depth specific samples) indicating a zone where salts (e.g., gypsum) preferably precipitate (sample index see Table in "Appendix"); $\mathbf{b}$ anions and cations from water extractions of

evaluations on several calcareous stones show a continuous increase of roughness is detectable, indicating the solution of the calcite stone (Grimm and Völkl 1983). The surface deterioration is very much dependent on the exposition. Higher deterioration correlated roughness is detectable on the weather-exposed side within a factor of 1.5 in correlation to the protected side. Grimm and Völkl (1983) measured $0.002-0.005 \mathrm{~mm} /$ year material loss on the weather-exposed side for the investigated stones. On the Krensheimer Muschelkalk at Cologne cathedral, a surface roughness is observable (Fig. 13a). The calculated rate of diluted calcium ions from one square meter of Krensheimer Muschelkalk with a matrix density of $2.72 \mathrm{~g} / \mathrm{cm}^{3}$ (Lukas 1990), a calcium concentration of 37.14 wt. \% and an average thickness of material loss due to corrosion of $0.0035 \mathrm{~mm} /$ year is about $9.52 \mathrm{~g} / \mathrm{sq} \mathrm{m}$ year Krensheimer Muschelkalk and thus $3.54 \mathrm{~g} / \mathrm{sq} \mathrm{m}$ year Ca. This would correlate to $12 \mathrm{~g} / \mathrm{sq} \mathrm{m}$ year $\mathrm{CaSO}_{4}$ or $15.2 \mathrm{~g} / \mathrm{sq} \mathrm{m}$ year gypsum $\left(\mathrm{CaSO}_{4} \cdot 2 \mathrm{H}_{2} \mathrm{O}\right)$. The possibly diluted calcium ions are probably not transferred into gypsum at a 1:1 ratio. The higher share is probably lost as dust in air turbulences.

The acid buffering capacity of eight tested natural building stones was measured by titration with hydrochloric acid and the resulting solute ions buffering the acid at $\mathrm{pH} 4$ were detected. As expected, the experiments on the eight tested stones revealed similar amounts for volcanic stones and sandstones. The carbonate-rich sandstone (Schlaitdorfer sandstone) buffers a volume of $\mathrm{HCl}$, which is 12 times higher. The limestone (Krensheimer Muschelkalk) shows an acid-binding capacity enlarged by factor 320 (Fig. 13b). On the one hand, these experiments indicate a higher liability for crust formation of stone with deteriorated stone material (IC-analysis) indicating high salt concentrations in the disaggregated material on the reverse of scales as well as in other deteriorated material

higher acid binding capacity. On the other hand, they reflect that upon an acidic impact the limestone also readily solutes and provides calcium ions, which therefore may be transported to other stones and contribute to the formation of gypsum crusts (Fig. 14).

In terms of a stone-immanent calcium source, it must firstly be considered that Drachenfels trachyte as host rock has a low calcium concentration, which is mainly associated with feldspars as rock-forming minerals, e.g., plagioclases. The decrease of the alkali metals within the crust $\left(\mathrm{K}_{2} \mathrm{O} 10-28 \%\right.$ and $\mathrm{Na}_{2} \mathrm{O}$ of $\left.0.5-27 \%\right)$ indicates certain feldspar corrosion. However, the much higher calcium concentration of the investigated crusts in respect to the host rock indicates an external source for calcium and a stone-immanent calcium source is of minor impact.

Interferences of adjacent stones

Already Kraus (1985a, b), Mirwald et al. (1988) and von Plehwe-Leisen et al. (2007) noted that there are strong indications that the decay of the Drachenfels trachyte is especially critical when it is placed adjacent to carbonate stones. Investigations on site reveal that crust formation on Drachenfels trachyte can be enhanced by neighboring limestone, depending on the exposition of the affected section of the wall (Fig. 14). Krensheimer Muschelkalk exposed to an acidic environment solutes into its ion compounds. Rainwater leaches the rock components of the limestone. This calcium ion loaded water runs off and is directly transported to the building stones in the flow direction. It is absorbed by the Drachenfels trachyte and accumulates in the cavities. Additionally, these cavities are 
Fig. $18 \mathrm{~K}_{2} \mathrm{O}$ depletion and $\mathrm{H}_{2} \mathrm{O}$ increase in deterioration samples indicating the formation of phyllosilicates (sample index see in "Appendix")

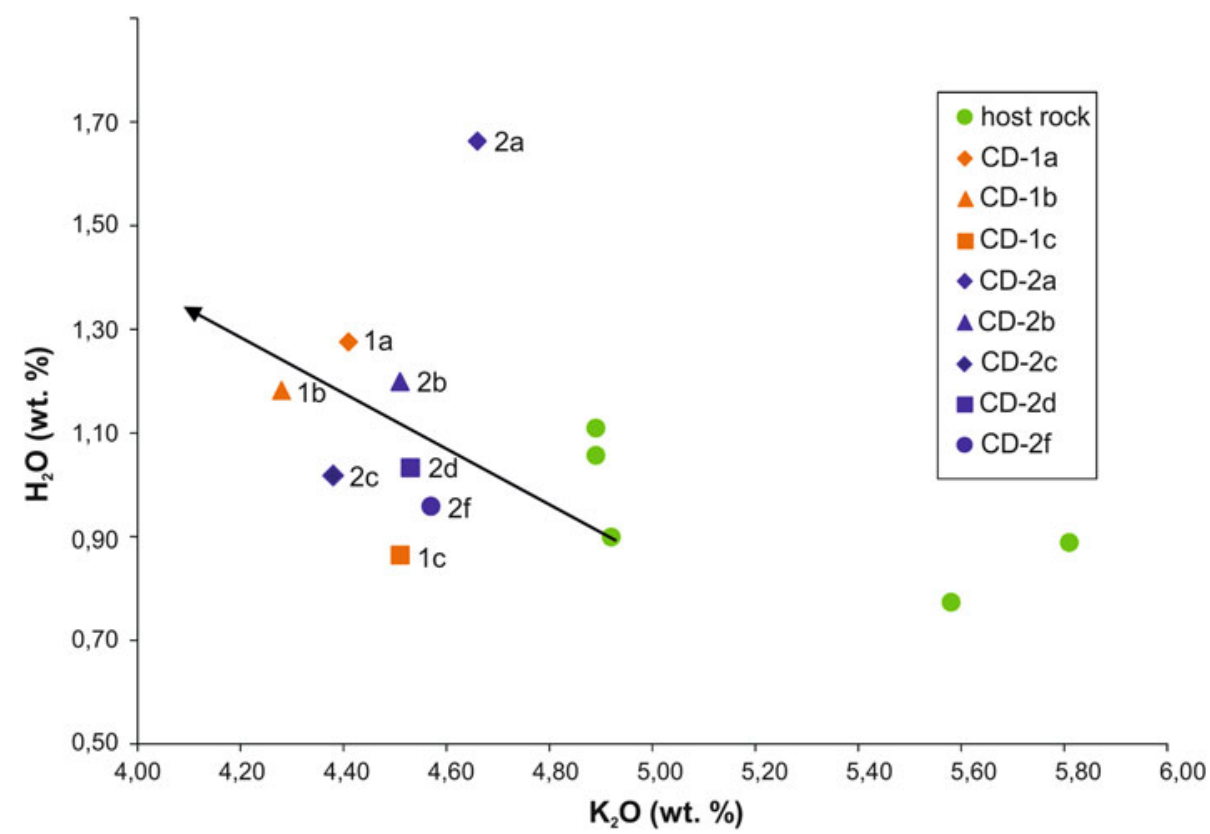

a preferred location for the deposition of pollutants-on the one hand due to the rock's surface character and secondly due to the better adsorption of airborne particles onto humid surfaces (Charola and Ware 2002). Due to the environmental impact of sulfuric pollutants, salt, e.g., gypsum, formation takes place. As illustrated in Fig. 14, the affected wall section has to be in the relevant flow direction. Water transport and input have to be in a relation allowing enough ions to be dissolved and transported. At the same time, the appropriate amount of water has to guarantee the formation and precipitation of salts. This means that interferences are strongly dependent on the exposition of the wall section concerned and the placement of adjacent stones in relation to each other. However, neighboring calcareous stones do not play an initial role in the formation of crusts, but may contribute if extrinsic factors such as environmental impact, exposition, and localization are already present.

The Drachenfels trachyte not only shows enhanced crust formation and stronger decay in cavities, but also along joints. These deterioration features can be ascribed to the dissolution of alkaline components of the mortars as well as to a perturbation of the flow of water.

The dissolution of the carbonate rock and the impact of alkaline components increase the $\mathrm{pH}$ of the floating solutions. The Drachenfels trachyte with a $\mathrm{SiO}_{2}$-content $>63 \%$ due to the quartz concentration (13\%) and the high abundance of feldspars, can be referred to as an acid silicate rock. If the described alkaline waters come into contact with the Drachenfels trachyte, a stronger deterioration of the volcanic rock takes place, because of the increased solution of quartz and feldspars in alkaline milieu.
Furthermore, a higher $\mathrm{pH}$ together with the calcite particles increases the oxidation rate for $\mathrm{SO}_{4}{ }^{2-}$ from $\mathrm{SO}_{2}$ (Charola and Ware 2002; Zappia et al. 1998). Wiese et al. (2012) ascertained that for the deposition velocity of $\mathrm{SO}_{2}$ on silicate stone the relative humidity is not as relevant as the buffering capacity available for the dissolution reaction of $\mathrm{SO}_{2}$. The solubility of $\mathrm{SO}_{2}$ strongly decreases with decreasing $\mathrm{pH}$. Therefore, a rise of $\mathrm{pH}$ through the impact of calcite adjacent stones may enhance $\mathrm{SO}_{2}$ deposition velocity and contribute to the sulfation process. If the aforementioned extrinsic factors are present, these aspects contribute to a stronger crust formation on the Drachenfels trachyte.

Continuous in situ measurements of temperature and humidity inside the different stone materials indicate higher water content for the Krensheimer Muschelkalk than for the Drachenfels trachyte at a depth of $32 \mathrm{~mm}$ (Fig. 15a). It can be seen, that the data logger in the Drachenfels trachyte with little distance to the Krensheimer Muschelkalk shows higher values of relative humidity than the data logger in the center of the ashlar (Fig. 15b). These observations may indicate on the one hand a higher water import through the joints, where the alkaline mortar sits. On the other hand, the Krensheimer Muschelkalk might serve as a long-term source of water for the Drachenfels trachyte. In both cases, the Drachenfels trachyte is provided with ion-loaded water over an extended period of time, where this stone would not have absorbed either as much water or as high a volume of alkaline components. Even though no direct water flow over the surface of the stone is provided, a potential import of alkaline components arises, raising the $\mathrm{pH}$ and delivering ions for the formation of damaging salts. 
Fig. 19 The very fine recrystallized grain structure of the altered volcanic glass fractions in the interstitial area of the Drachenfels trachyte show high and distinct porosity (microprobe backscattered electron image in composition mode)

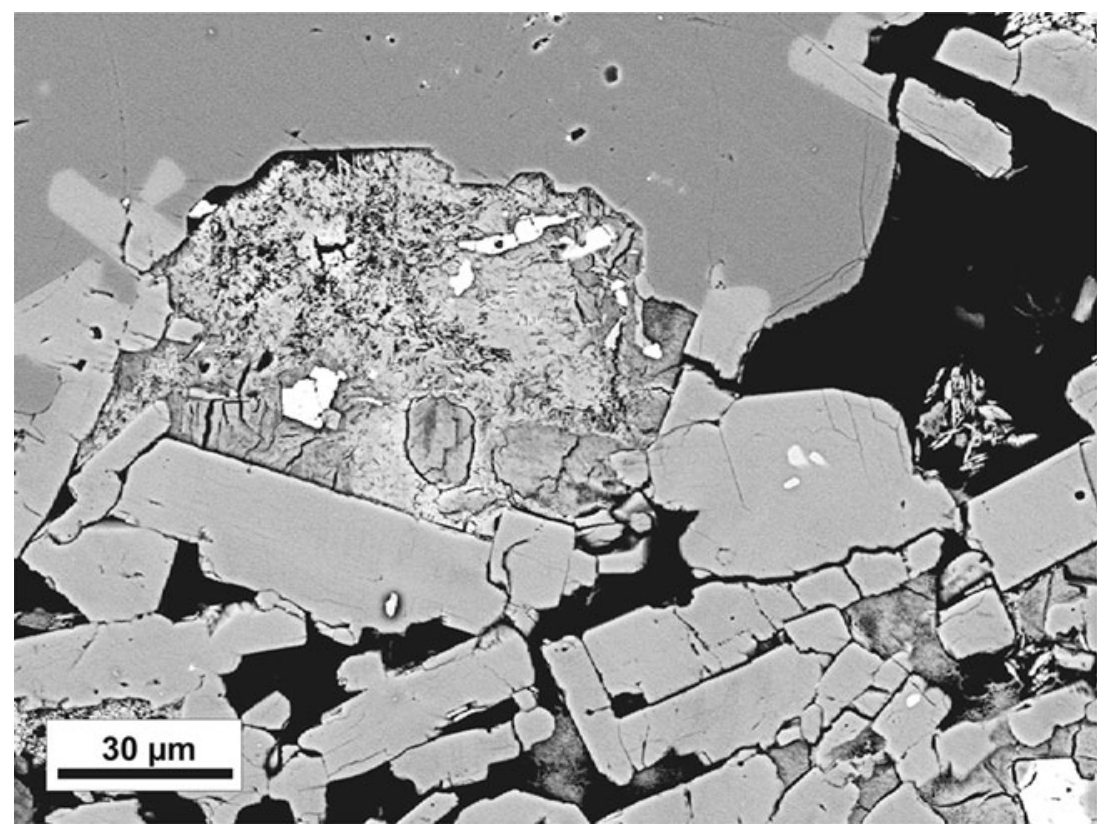

Exposition and crust formation

Besides the question of material import as a factor for crust formation, another vital point is the surface character and exposition of the building stone. Laminar crusts are observed on vertical and smooth stone surfaces. Black framboidal crusts build in sheltered areas and show significant formation in cavities on even stone surfaces as well. In sheltered areas, the dry deposition of particulate matter is stronger than onto unprotected surfaces. A higher pollutant concentration and higher moisture are expected leading to significant acidity (Charola and Ware 2002). Due to relevant air turbulences in sheltered areas the transport mechanisms provoke an accumulation of airborne particles. These particles are then firmly deposited and are not washed off by direct rain water. The necessary moisture for the crust formation is provided by higher relative humidity, especially in the case of fog or dew (Amoroso and Fassina 1983; Del Monte and Rossi 1997) as well as by indirect water input (Kraus 1985a, b). Furthermore, these protected zones stay moist for longer, further contributing to adhesion conditions appropriate for the deposition of particles. The deposition of particles provides nucleation sites for the growth of gypsum crystals (Charola and Ware 2002; Sabbioni 2003), which develop better in sheltered, protected zones, where evaporation is retarded. The morphology of these framboidal crusts provides a larger reaction surface, not only for intensive particulate deposition, but also for the condensation of fog and dew or high relative humidity in general. This clearly indicates that the growth of framboidal crusts is an exponential reaction.
Correlation of crust formation and stone decay

The investigation shows that crust formation is strongly correlated to the structural disintegration of the Drachenfels trachyte. Depth-specific samples and analyses reveal a gypsum distribution, which is coherent with the detected decay phenomena. Microscopic, SEM and EDX analyses clearly indicate that gypsum enrichment is not only found within the crust but also in deeper zones of the disintegrated stone material. In deteriorated areas, gypsum accumulates in cracks (Fig. 16a) and on the backside of the detached scales, where significant gypsum formation is observed (Fig. 16b). The disaggregated stone material underneath the scale is the zone where salts, e.g., gypsum, mainly precipitate and the highest concentrations are found (Fig. 17a). In deeper zones of the stone, sulfur decreases as the stone material becomes unaffected by environmental impact and salt migration as the analyses of drill cores reveal (Fig. 17a).

Dependent on the moisture distribution in the building stone, a zone of maximum moisture defines. In this zone, salts preferably accumulate and precipitate, causing structural disintegration and leading to a zone of disruption (Snethlage and Wendler 1997). Gypsum has a comparably low solubility and shows little migration; therefore, it tends to accumulate in the pore space (Charola et al. 2007). Higher moisture conditions, e.g., retarded drying due to pore clogging through gypsum or crust formation, allow for an increased solubility and migration of the less soluble gypsum (Charola et al. 2007, 346f). A small amount of the oversaturated gypsum in the pore space is diluted again. If the diluted gypsum recrystallizes in fissures or interstitial areas at grain contacts, the stress induced by the growth 

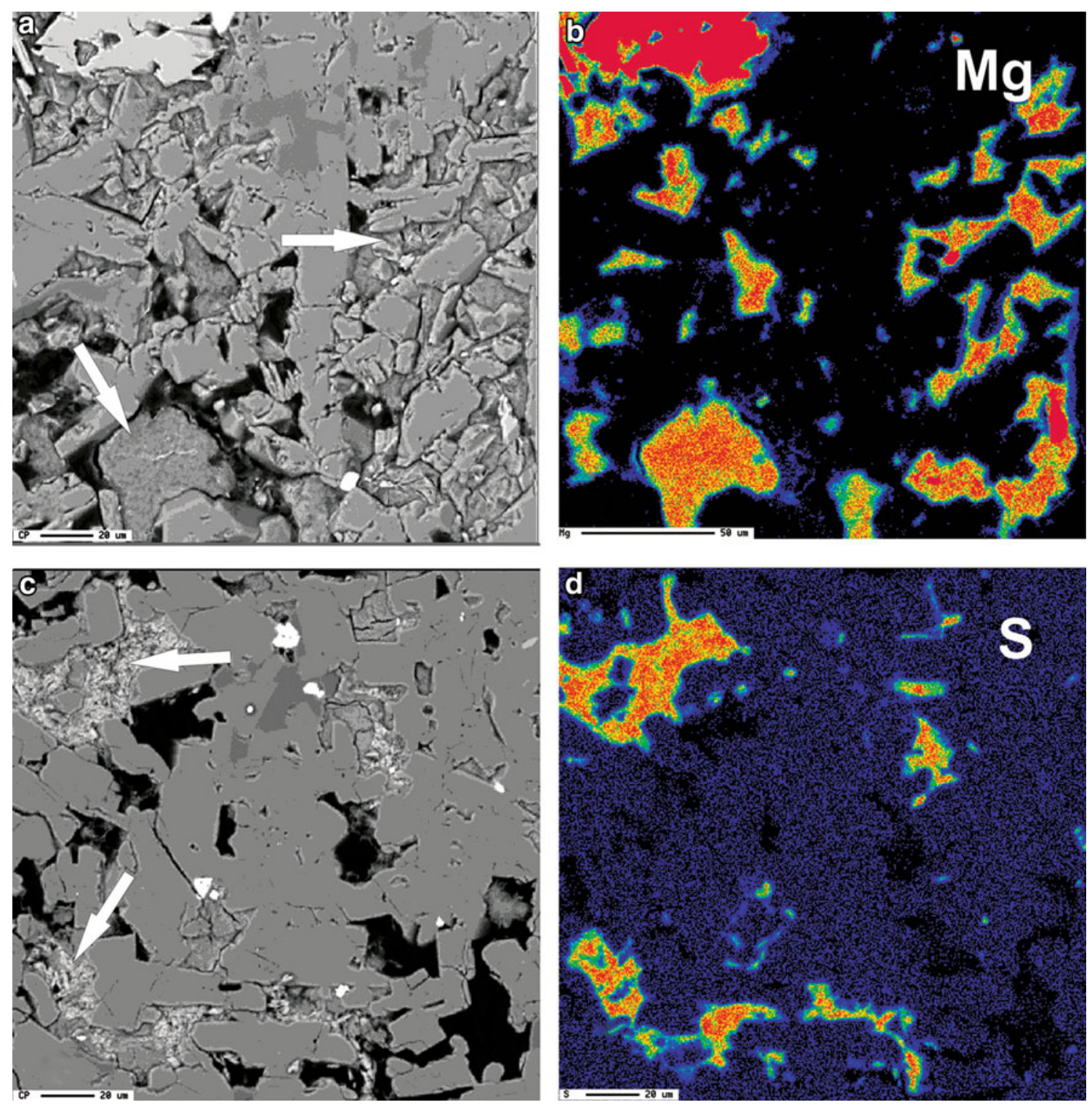

Fig. 20 Microprobe mapping a backscattered electron image in composition mode of unweathered Drachenfels trachyte, arrows marking areas of altered volcanic glass fractions; b magnesium mapping of the same area as Fig. 20a, the yellow-orange-red areas indicate higher magnesium concentration of the altered volcanic glass fractions; c backscattered electron image in composition mode of

of gypsum crystals may cause the disintegration of the fabric (Charola et al. 2007). Furthermore, calcium sulfate solutions tend to supersaturate and may provide for the generation of high crystallization pressures (Steiger 2005).

Salt analyses confirm the on-site observations and SEM analyses. Gypsum is found in the water extractions from scale samples, and the enrichment of $\mathrm{Ca}$ and $\mathrm{SO}_{4}{ }^{2-}$ is significantly higher in the disaggregated zone and the backside of the scales (Fig. 17b). In the samples of flaking and crumbling, high concentrations of $\mathrm{Ca}$ and $\mathrm{SO}_{4}{ }^{2-}$ are detected as well (Fig. 17b). This indicates that even though the gypsum content in the crusts themselves is not as high

weathered Drachenfels trachyte, arrows marking areas of pore spaces filled with gypsum. The altered glass fractions are originally located in these interstitial areas, but are now replaced through secondary gypsum formation; d sulfur mapping of the same area as Fig. 20c, the yellow-orange-red areas marking higher sulfur concentration as an indication of gypsum

as in the crusts built on limestone, gypsum clearly contributes to the damage process of flaking, scaling, and crumbling to total fabric collapse of the Drachenfels trachyte.

Structurally disturbed zones, where no gypsum is found, are detected as well (Fig. 16c). This suggests that preexisting fabric and especially mineral in-homogeneities are disrupted due to a chemical and mechanical deterioration impact. Microscopic analyses not only show the displacement of separate grains, but also detect the opening of cleavage surfaces in minerals and their disruption (Fig. 16d). Leaching experiments on the Drachenfels 
trachyte in different $\mathrm{pH}$ solutions show the dilution of alkali and alkaline earth metals ( $\mathrm{Na}, \mathrm{K}, \mathrm{Mg}, \mathrm{Ca})$, indicating feldspar breakdown. The chemical analyses show a decrease of $\mathrm{K}_{2} \mathrm{O}(14 \%)$ and an enrichment of $\mathrm{H}_{2} \mathrm{O}(22 \%)$ in the depth-specific samples, indicating clay mineral, e.g., kaolinite, formation from the alteration of feldspars and volcanic glass fractions (Fig. 18).

Scanning electron microscopy analyses detect high porosity of the aforementioned altered volcanic glass fractions of the mesostasis (Fig. 19). Due to the high capillarity of the altered glass fractions caused by the distinct porosity of their very fine recrystallized grain structure, these interstitial fillings are very sensitive to penetrating pore water. Vieten (1961) and Koch (2006) attribute a certain content of montmorillonite to these recrystallized glass fractions. Microprobe analyses identify the areas of altered glass fractions through higher magnesium concentrations (Fig. 20a, b). If sections of unweathered stone material (Fig. 20a, b) are compared to altered material (Fig. 20c, d), the interstitial area of the fabric, where the glass fraction is originally located, seems to be replaced by secondary gypsum formation (Fig. 20c, d).

These observations lead us to a model for the deterioration of the Drachenfels trachyte. Primarily through a certain water uptake of the Drachenfels trachyte ion-loaded water reaches the pore space. Mechanical and chemical deterioration processes of the rock-forming minerals take place: moisture dilatation provokes a grain displacement. Snethlage et al. (1996) ascertained a three- to fourfold higher hydric expansion induced by a saturated gypsum solution compared to dilatation with pure water. Mineral grains corrode and decompose along inherent weak points, e.g., cleavage planes as predetermined breaking points. These processes enlarge the pore space, giving rise to water impact and import of pollutants. Due to the higher concentration of pollutants in the pore water and a decrease of $\mathrm{pH}$, the chemical corrosion of the rock-forming minerals increases, resulting in the further comminution of the mineral grains and the disintegration of the fabric (Fig. 16c). With increasing moisture supply, the fractions of altered volcanic glass in the aforementioned mesostasis become more affected. Due to the changes of pore space forming new pathways and the high capillarity of the interstitial areas of recrystallized volcanic glass, the ionloaded water penetrates into the interstitial areas and gypsum accumulates. Due to the confinement of the gypsum in these delimited areas and the continuous crystal growth provided by the transport from the supersaturated gypsum solution high crystallization pressures are generated (Steiger 2003). The swelling and shrinking behavior of the montmorillonite may further contribute to degradation and mechanical deterioration processes.

Through the corrosion of the rock-forming minerals and the degradation of the altered volcanic glass fractions, porosity changes, and salt solutions are given new pathways. With repetitive wetting and drying cycles, different zones of moisture and evaporation form, and the ion content of the pore water increases. Salts precipitate, produce and manifest the displacement of the grains; hence the structural disintegration. The interaction of these decay mechanisms is characterized by their coupled feedback mechanism, e.g., moisture dilatation is much more significant in the presence of salts, leading to structural degradation (Snethlage et al. 1996; Snethlage and Wendler 1997). Where dilatation processes have been reversible in salt-free systems, they become intensified and irreversible in salt-containing systems. Due to constantly repeating dilatation and contraction processes caused by moisture, temperature, and ionic species (salts), grains are permanently displaced relative to each other. The deterioration processes are interactive leading to proceeding decay phenomena from surface parallel formation, e.g., scaling and flaking, to non-directional manifestations such as crumbling. Surface deterioration may start with crust
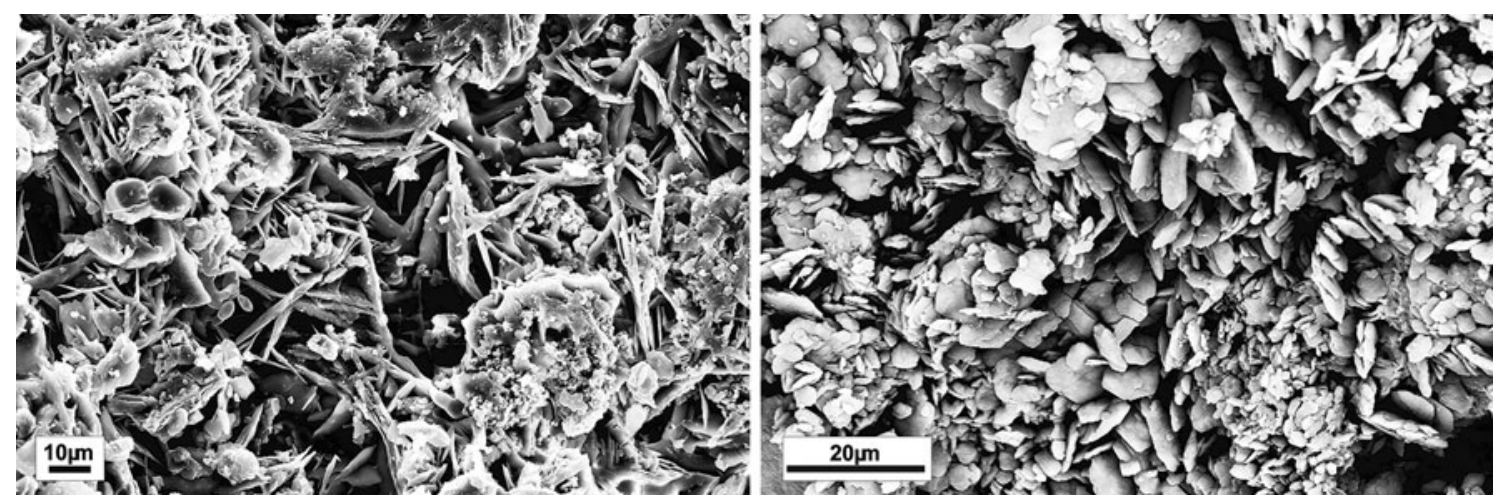

Fig. 21 SEM picture of gypsum formation on samples a from Cologne, showing an accumulation of large gypsum crystals; $\mathbf{b}$ from Altenberg, displaying gypsum crystals of smaller grain size and number 
formation as well as contour scaling and the detachment of these scales. The weathered surface may then progress into flaking and crumbling, resulting in total fabric collapse.

\section{Conclusions}

Investigations on the crust formation on Drachenfels trachyte clearly identify the impact of pollution. The elevated contents of $\mathrm{S}, \mathrm{Ca}, \mathrm{As}, \mathrm{Pb}, \mathrm{Sb}, \mathrm{Bi}$, and $\mathrm{As}$ in the crusts result from the impact of anthropogenic pollution mainly deriving from combustion. The analyses show an enrichment of sulfur associated with the higher abundance of gypsum. The lack of an important intrinsic source for calcium and sulfur in the Drachenfels trachyte for the formation of gypsum crusts demonstrates the major environmental impact of pollution as a source. Although $\mathrm{SO}_{2}$ in air has shown a strong decrease in concentration over the past 30 years, the pollutants are still present in the building stones and degradation in context with weathering crusts is still observed. This indicates that not only recent emission but also the pollutant concentrations of the past have to be considered and that the impact of particulate matter in the form of settling dust plays an important role today.

In addition, the formation of gypsum crusts can be enhanced by interferences between different building materials, e.g., mortars and adjacent stones (e.g., limestone). Furthermore, the surface character and exposition of the relevant building stones pose a crucial question for the formation of the weathering crusts, promoting or hindering the deposition of settling dust, as well as the formation processes coupled to corresponding moisture supply.

If gypsum formation is compared using the data obtained from the three between the three different cathedrals, the data from XRF analyses are consistent with the observations under the SEM. Gypsum formation on samples from Cologne shows a high accumulation of large, occasionally rosette-like, gypsum crystals. In comparison, gypsum crystals in Xanten are smaller and less abundant. In the samples from Altenberg, the gypsum crystals are even finer grained and normally only present in the form of a salt efflorescence (Fig. 21). These observations correlate well to the environmental $\mathrm{SO}_{2}$ concentrations and the intensity of the decay at the different locations. The trace element distribution in the crusts from industrial areas shows increasing values for lead and other heavy metals, which generally can be linked as typical pollutants to traffic and industry.

Although crust formation on the Drachenfels trachyte is not as significant as on limestone, black crust formation on the silicate stone more strongly correlates with structural degradation. The formation of gypsum crusts and salt deterioration play an essential part in the structural disintegration of the Drachenfels trachyte. The chemical corrosion of the rockforming minerals and the further alteration of volcanic glass fractions also contribute to the disintegration, besides mechanical decay processes. Mechanical deterioration processes (e.g., frost weathering, moisture dilatation) in a feedback mechanism with chemical corrosion of rock-forming minerals, degradation due to salt deterioration and swell-able clay minerals lead to an exponential disintegration of the rock fabric to total material collapse. The environmental impact in terms of pollutant import as well as climatic factors plays a key role.

A model for the deterioration of the Drachenfels trachyte is therefore concluded: gypsum crusts enhance moisturerelated deteriorationprocesses by hindering drying. Moisture and temperature cycles as well as varying moisture distribution promote the enrichment of gypsum in characteristic zones. Moisture dilatation is enhanced by the presence of gypsum salts. The acidic impact of anthropogenic pollution, e.g., the $\mathrm{SO}_{2}$ and $\mathrm{NO}_{x}$ concentrations in the atmosphere and the import of pollutants, leads to chemical weathering in the form of the alteration of feldspars and volcanic glass fractions. This is shown by the structural degradation and corrosion of the minerals and the increase of $\mathrm{H}_{2} \mathrm{O}$ concentration. These chemical and physico-mechanical decay processes open the pore space through mineral comminution and grain displacement. The fabric becomes structurally impaired and the pore space is altered, thus water and pollutant import increases. Through these newly opened pathways gypsum, which usually scarcely migrates, reaches the interstitial areas of high capillarity. In these confined areas, the crystallization of gypsum possibly generates high crystallization pressures. The sum of these factors leads to stress and fabric decomposition as well as the degradation of the rock-forming minerals; hence the deterioration of the stone in the form of scaling, flaking, and crumbling.

Regarding these deterioration mechanisms as solitary processes, not a single one is distinctively significant or could be addressed as the key mechanism for the deterioration of the Drachenfels trachyte. However, their feedback interaction and their permanent repetition in continuous cycles lead to a material fatigue, which finally results in the collapse of the material.

Acknowledgments This work is supported by the Deutsche Bundesstiftung Umwelt (DBU-AZ-28253-45). We would also like to thank B. Schock-Werner and the maintenance department at the Cologne cathedral. Thanks go to J. Schubert and T. Knapp from Xanten cathedral as well as the colleagues at Altenberg cathedral for supporting our work. We are grateful to D. and K. Kirchner, German Mining Museum Bochum, for SEM and IC analyses. The authors also thank the anonymous reviewer for the critical review and the helpful comments to improve the manuscript.

Open Access This article is distributed under the terms of the Creative Commons Attribution License which permits any use, distribution, and reproduction in any medium, provided the original author(s) and the source are credited. 


\section{Appendix}

Table 9 Index of analyzed samples

\begin{tabular}{|c|c|c|c|}
\hline Sample code & Cathedral & Stone & Descripton \\
\hline DT-1 & - & Drachenfels trachyte & Host rock \\
\hline DT-2 & - & Drachenfels trachyte & Host rock \\
\hline DT-3 & - & Drachenfels trachyte & Host rock \\
\hline DT-4 & - & Drachenfels trachyte & Host rock \\
\hline DT-5 & - & Drachenfels trachyte & Host rock \\
\hline AL-01 & Altenberg & Drachenfels trachyte & Laminar crust \\
\hline AL-02 & Altenberg & Drachenfels trachyte & Laminar crust \\
\hline AL-03 & Altenberg & Drachenfels trachyte & Laminar crust \\
\hline AF-04 & Altenberg & Krensheimer Muschelkalk & Framboidal crust \\
\hline CL-01 & Cologne & Drachenfels trachyte & Laminar crust \\
\hline CL-02 & Cologne & Drachenfels trachyte & Laminar crust \\
\hline CL-03 & Cologne & Drachenfels trachyte & Laminar crust \\
\hline CL-04 & Cologne & Drachenfels trachyte & Laminar crust \\
\hline CL-05 & Cologne & Drachenfels trachyte & Laminar crust \\
\hline CL-06 & Cologne & Drachenfels trachyte & Laminar crust \\
\hline CL-07 & Cologne & Drachenfels trachyte & Laminar crust \\
\hline CL-08 & Cologne & Drachenfels trachyte & Laminar crust \\
\hline CF-09 & Cologne & Drachenfels trachyte & Framboidal crust \\
\hline CF-10 & Cologne & Drachenfels trachyte & Framboidal crust \\
\hline CF-11 & Cologne & Krensheimer Muschelkalk & Framboidal crust \\
\hline XL-01 & Xanten & Drachenfels trachyte & Laminar crust \\
\hline XL-02 & Xanten & Drachenfels trachyte & Laminar crust \\
\hline XL-03 & Xanten & Drachenfels trachyte & Laminar crust \\
\hline XL-04 & Xanten & Drachenfels trachyte & Laminar crust \\
\hline XL-05 & Xanten & Drachenfels trachyte & Laminar crust \\
\hline XF-06 & Xanten & Drachenfels trachyte & Framboidal crust \\
\hline CD-la & Cologne & Drachenfels trachyte & Scale (0.5 mm thickness) \\
\hline $\mathrm{CD}-\mathrm{lb}$ & Cologne & Drachenfels trachyte & Drill core behind scale $(0-10 \mathrm{~mm})$ \\
\hline CD-lc & Cologne & Drachenfels trachyte & Drill core behind scale $(11-31 \mathrm{~mm})$ \\
\hline $\mathrm{CD}-2 \mathrm{a}$ & Cologne & Drachenfels trachyte & Scale (1 mm thickness) \\
\hline $\mathrm{CD}-2 \mathrm{~b}$ & Cologne & Drachenfels trachyte & Disaggregated material behind scale \\
\hline $\mathrm{CD}-2 \mathrm{c}$ & Cologne & Drachenfels trachyte & Decay material from flaking \\
\hline $\mathrm{CD}-2 \mathrm{~d}$ & Cologne & Drachenfels trachyte & Drill core behind scale $(0-10 \mathrm{~mm})$ \\
\hline $\mathrm{CD}-2 \mathrm{e}$ & Cologne & Drachenfels trachyte & Decay material crumbled area \\
\hline $\mathrm{CD}-2 \mathrm{f}$ & Cologne & Drachenfels trachyte & Drill core behind scale $(11-31 \mathrm{~mm})$ \\
\hline $\mathrm{CD}-07$ & Cologne & Drachenfels trachyte & Disaggregated material behind scale \\
\hline CD-08 & Cologne & Drachenfels trachyte & Disaggregated material behind scale \\
\hline CS-01 & Cologne & Obernkirchner Sandstein & Dust surface deposition \\
\hline
\end{tabular}

\section{References}

Adamo P, Violante P (2000) Weathering of rocks and neogenesis of minerals associated with lichen activity. Appl Clay Sci $16: 229-256$

Amoroso GG, Fassina V (1983) Stone decay and conservation. Elsevier, Amsterdam, pp 1-453
Antill SJ, Viles HA (1999) Deciphering the impacts of traffic on stone decay in Oxford: some preliminary observations from old limestone walls. In: Jones MS, Wakefield RD (eds) Aspects of stone weathering, decay and conservation. Imperial College Press, London, pp 28-42

Armstrong JT (1991) Quantitative elemental analysis of individual microparticles with electron beam instruments. In: Heinrich KFJ, 
Newbury DE (eds) Electron probe quantitation. Plenum Press, New York, pp 261-315

Armstrong JT (1995) CITZAF: a package of correction programs for the quantitative electron microbeam $\mathrm{X}$-ray analysis of thick polished materials, thin films, and particles. Microbeam Anal 4:177-200

Arnold A (1981) Salzmineralien in Mauerwerken. Schweiz Mineral Petrogr Mitt 41:147-166

Ausset P, Bannery F, Lefèvre RA (1992) Black-crust and air microparticles contents at Saint-Trophime, Arles. In: Delgado Rodrigues J, Henriques F, Telmo Jeremias F (eds) 7th International congress on deterioration and conservation of stone. Lab. Nat. Engenharia Civil, Lisbon, pp 325-334

Barcellona-Vero L, Montesila M (1978) Mise en évidence de l'activité des thiobacilles dans les altérations des pierres á Rome. In: symposium deterioration and protection of stone monuments, Paris, Publ Nr 4.1

Bergmann J, Friedel P, Kleeberg R (1998) BGMN: a new fundamental parameters based Rietveld program for laboratory X-ray sources, its use in quantitative analysis and structure investigations. CPD Newslett 20(Summer):5-8

Berres F (1996) Gesteine des Siebengebirges. Rheinlandia, Siegburg $141 \mathrm{p}$

Bläuer-Böhm C (2005) Quantitative salt analysis in conservation of buildings. In: Restoration of buildings and monuments. Bauinstandsetzen und Baudenkmalpflege 11(6):409-418

Bonazza A, Sabbioni C, Ghedini N, Favoni O, Zappia G (2004) Carbon data in black crusts on European monuments. In: SaizJimenez C (ed) Air pollution and cultural heritage. Taylor and Francis, London, pp 39-46

Bonazza A, Sabbioni C, Ghedini N (2005) Quantitative data on carbon fractions in interpretation of black crusts and soiling on European built heritage. Atmos Environ 39:2607-2618

Bonazza A, Sabbioni C, Ghedini N, Hermosin B, Jurado V, Gonzalez JM, Saiz-Jimenez C (2007) Did smoke from Kuwait oil well fires affect Iranian archeological heritage? Environ Sci Technol 41:2378-2386

Brimblecombe P (2003) The effects of air pollution on the built environment. Air Pollut Reviews, vol 2. Imperial College Press, London

Brocco D, Giovagnoli A, Laurenzi-Tabasso M, Marabelli M, Tappa R, Polesi R (1988) Air pollution in Rome and its role in the deterioration of porous building materials. Durab Build Mater 5:393-408

Camuffo D (1995) Physical weathering of stone. Sci Total Environ 167:1-14

Charola AE, Ware R (2002) Acid deposition and the deterioration of stone: a brief review of a broad topic. In: Siegesmund $\mathrm{S}$, Vollbrecht A (eds) Natural stone, weathering phenomena, conservation strategies and case studies. Geological Society, London, Special publication 205, pp 393-406

Charola AE, Pühringer J, Steiger M (2007) Gypsum: a review of its role in the deterioration of building materials. Environ Geol 52:339-352

Del Monte M, Rossi P (1997) Fog and gypsum crystals on building materials. Atmos Environ 31:1637-1646

Del Monte M, Vittori O (1985) Air pollution and stone decay: the case of Venice. Endeavoir 9:117-122

Del Monte M, Sabbioni C, Vittori O (1981) Airborne carbon particles and marble deterioration. Atmos Environ 15:645-652

Del Monte M, Ausset P, Forti P, Lefèvre RA, Tolomelli M (2001) Air pollution records on selenite in the urban environment. Atmos Environ 35:3885-3896

Derbez M, Lefèvre RA (1996) Le contenu microparticulaire des croûtes gypseuses de la Cathédrale Saint-Gatien de Tours: comparaison avec l'air et la pluie. In: Riederer J (ed)
Proceedings of the 8 th international congress on deterioration and conservation of stone, Möller, Berlin, pp 359-370

Do J (2000) Untersuchung der Verwitterung von Fassaden aus Naturstein-Vergleich an den Gebäuden der Museumsinsel in Berlin. University of Berlin, Diss

Dornieden T, Gorbushina A (2000) New methods to study the detrimental effects of poikilotroph microcolonial micromycetes (PPM) on building materials. In: Fassina V (ed) Proceedings of the 9th international conference on deterioration and conservation of stone, vol 1. Elsevier, Amsterdam, pp 461-468

Efes Y, Lühr HP (1976) Natursteine am Bauwerk des Kölner Doms und ihre Verwitterung. In: Kölner Domblatt 41:167-194

Esbert RM, Diaz-Pache F, Alonso FJ, Ordaz J, Wood GC (1996) In: Riederer J (ed) Proceedings of the 8th international congress on deterioration and conservation of stone, vol 1. Möller, Berlin, pp 393-399

Fassina V (1988) Environmental pollution in relation to stone decay. Durab Build Mat 5:317-358

Fassina V, Favaro M, Naccari A (2002) Principal decay patterns on Venetian Monuments. In: Siegesmund S, Weiss T, Vollbrecht A (eds) Natural stones, weathering phenomena, conservation strategies and case studies. Geological Society, London, pp 381-391 Special publication 205

Fitzner B, Heinrichs K, Kownatzki R (1995) Weathering forms: classification and mapping. In: Snethlage R (ed) Denkmalpflege und Naturwissenschaft, Natursteinkonservierung I. Ernst und Sohn, Berlin, pp 41-88

Frediani P, Malesani PG, Vanucci S (1976) Weathering of Florentine stones: sulfatation and its determination. In: 2nd International symposium on deterioration of building stones, pp 117-118

Fuchs G (2006) Allgemeine Mikrobiologie. Georg Thieme, Stuttgart, pp 321-340

Furlan V, Girardet E (1983) Considerations on the rate of accumulation and distribution of sulphurous pollutants in exposed stones. In: Wittmann EH (ed) Materials science and restoration. Lack und Chemie, Filderstadt, pp 285-290

Graue B, Siegesmund S, Middendorf B (2011) Quality assessment of replacement stones for the Cologne Cathedral: mineralogical and petrophysical requirements. Environ Earth Sci 63:1799-1822

Grimm WD, Völkl J (1983) Rauhigkeitsmessungen zur Kennzeichnung der Naturwerkstein-verwitterung/[Measurement of Roughness for Characterization of Building Stone Decay] ZDGG 134:387-411

Grün R (1931) Die Verwitterung von Steinen. In: Die Denkmalpflege, 33:168-183

Henley, K (1967) In: Proceedings clean air conference. Blackpool, pp 55-60

Hughes JJ, Bartos PM, Cuthbert SJ, Stewart RN, Valek J (1998) Microstructures in historic Scottish lime mortars. In: Jones MS, Wakefield RD (eds) Stone Weathering and Atmospheric Pollution Network. Imperial College Press, London

IBS (1990) Untersuchungsbericht N-30/90 Altenberger Dom. Institut für Baustoffuntersuchung, Saarbrücken. Unpublished report

Johansson L-G, Lindqvist O, Mangio RE (1988) Corrosion of calcareous stones in humid air containing $\mathrm{SO}_{2}$ and $\mathrm{NO}_{2}$. In: Rosvall $\mathrm{J}$, Aleby $\mathrm{S}$ (eds) Air Pollution and Conservation. Safeguarding our Architectural Heritage. Elsevier, Amsterdam, pp 255-265

Jones D, Wilson MJ (1985) Chemical activity of lichens on mineral surfaces: a review. Int. Biodeterioration 5:99-104

Jones MS, Wakefield RD, Forsyth G (2000) A study of biological decayed sandstone with respect to $\mathrm{Ca}$ and its distribution. In: Fassina V (ed.) Proceedings of the 9th international conference on deterioration and conservation of stone, vol. 1. Elsevier, Amsterdam, pp 473-481

Kainka E, Kramert G, Dudzeviciusij J (1997) Characterization of particulate matter PM10 and PM2.5 in North Rhine Westphalia, 
Saxony, and Lithuania-first results Ann occup Hyg, vol 41. Elsevier, Amsterdam, pp 54-59

Kaiser E (1910) Wetterbeständigkeit einer Reihe von Kalksteinen mit besonderer Berücksichtigung der Verhältnisse am Cölner Dom. Unpupl. report, Gießen

Kieslinger A (1932) Zerstörung an Steinbauten-Ihre Ursachen und ihre Abwehr. Verlag Deuticke, Leipzig-Wien, p 346

Knacke-Loy O (1988) Verwitterungsdifferenzierungen von Stubensandstein-Bauteilen des Kölner Doms. Univ. Tübingen, Diss

Knacke-Loy O (1989) Der Schlaitdorfer Sandstein und seine unterschiedliche Verwitterungs-anfälligkeit am Kölner Dom. In: Kölner Domblatt 54:61-72

Knetsch G (1952) Geologie am Kölner Dom. Int. Journal Earth Science 40(1):57-73

Knöfel D (1979) Bautenschutz mineralischer Baustoffe. Bauverl, Wiesbaden, p 220

Koch R (2006) Trachyte aus dem Colli Euganei, Norditalien. In: Dombauhütte Köln (2006) Modellhafte Entwicklung von Konservierungskonzepten für den stark umweltgeschädigten Trachyt an den Domen zu Köln und Xanten. Unpubl. Report DBU, pp 9-42

Kraus K (1980) Verwitterungsvorgänge an Bausteinen des Kölner Doms: ein Beitrag zur Proble-matik der Naturstein-Verwitterung an Bau-Denkmälern im Stadtklima/Köln, Unpubl. University of Cologne, Cologne

Kraus K (1985a) Experimente zur immissionsbedingten Verwitterung der Naturbausteine des Kölner Doms im Vergleich zu deren Verhalten am Bauwerk. University of Cologne, Diss

Kraus K (1985b) Unterschiedliche Witterungsanfälligkeit der Kölner Dombausteine. In: Kölner Domblatt 50:101-104

Kraus K (2002) Lösliche Alkalien in neuen Mörteln (Bestimmung, Gehalte, Bewertung, Untersuchungsbedarf und erste Ergebnisse). In: IFS-Bericht Nr. 14, Salze im historischen Natursteinmauerwerk, pp 11-18

Kraus K, Droll K (2009) Investigations of soluble salt content in modern hydraulic lime mortars - test method and first results. In: Groot C (ed) RILEM proceedings pro 67: repair mortars for historic masonry, pp 207-213

Kraus K, Jasmund K (1981) Verwitterungsvorgänge an Bausteinen des Kölner Domes. In: Kölner Domblatt 46:175-190

Krumbein WE (1988) Biotransfer in monuments: a sociobiological study. Durab. Build. Mater. 5:359-382

LANUV (2010) Data from Landesamt für Natur, Umwelt und Verbraucherschutz Nordrhein-Westfalen. Köln-Rodenkirchen, Wesel-Feldmark, Netphen Rothaargebirge, Stationen

Lauer W, Bendix J (2004) Klimatologie. Das geographische Seminar 2 ed. Westermann, Braunschweig, p 352

Lefèvre RA, Ausset P (2002) Atmospheric pollution and building materials: stone and glass. In: Siegesmund S, Weiss T, Vollbrecht A (eds) Natural stones, weathering phenomena, conservation strategies and case studies. Geological Society, London, pp 329-345 Special publication 205

Lefèvre RA, Derbez M, Grégoire M, Ausset P (1998) Origin of sulphated gray crusts on glass in polluted urban atmosphere: the stained glass windows of Tours cathedral (France). Glass Science and Technology, Glastechnische Berichte 71:75-80

Luckat S (1973a) Ein Schnelltestgerät zur Prüfung von Resistenzverhalten mineralischer Baustoffe gegenüber Luftverunreinigungen. Dtsch Kunst und Denkmalpflege 31:51-53

Luckat S (1973a) Die Einwirkung von Luftverunreinigungen auf die Bausubstanz des Kölner Domes. Teil I. In: Kölner Domblatt 36/37:65-74

Luckat S (1974) Die Einwirkung von Luftverunreinigungen auf die Bausubstanz des Kölner Domes. Teil II. In: Kölner Domblatt 38/39:95-106
Luckat S (1975) Die Einwirkung von Luftverunreinigungen auf die Bausubstanz des Kölner Domes. Teil III. In: Kölner Domblatt 40:75-108

Luckat S (1977) Die Einwirkung von Luftverunreinigungen auf die Bausubstanz des Kölner Domes. Teil IV. In: Kölner Domblatt 42:151-188

Luckat S (1984) Beton, Stein und Eisen bricht. In: Guratzsch D (ed) Baumlos in die Zukunft. Kindler, München, pp 225-237

Lukas R (1990) Geologie und Naturwerksteine Baden-Württembergs. In: Grimm WD (ed.) Bildatlas wichtiger Denkmalgesteine der Bundesrepublik Deutschland. Arbeitsheft des Bayerischen Landesamtes für Denkmalpflege, Bd. 50, München, pp 147-162

Martinez GM, Martinez EN (1991) In: Studies in conservation 36:99-110

Mirwald PW, Kraus K, Wolff A (1988) Stone deterioration on the Cathedral of Cologne. In: Durability of building materials 3/4, Elsevier, Amsterdam, 5:549-570

Moroni B, Poli G (2000) Corrosion of limestone in humid air containing sulphur and nitrogen disoxides: a model study. In: Fassina V (ed) Proceedings of the 9th international conference on deterioration and conservation of stone, vol 1. Elsevier, Amsterdam, pp 367-374

Moropoulou A, Bisbikou K, Torfs K, Van Grieken R, Zezza F, Macri F (1998) Origin and growth of weathering crusts on ancient marbles in industrial atmosphere. Atmos Environ 32:967-982

Neumann HH, Steiger M, Wassmann A, Dannecker W (1993) Aufbau und Ausbildung schwarzer Gipskrusten und damit zusammenhängender Gefügeschäden von Naturwerksteinen am Beispiel des Leineschlosses (Hannover). Jahresbericht Steinzerfall Steinkonservierung 1991:150-167

Pinna D, Salvadori O (2000) Endolithic lichens and conservation: an underestimated question. In: Fassina V (ed) Proceedings of the 9th international conference on deterioration and conservation of stone, vol 1. Elsevier, Amsterdam, pp 513-519

Pohl W, Schneider J (2005) Geochemische einflüsse endolithischer mikroorganismen auf gesteinsoberflächen. Z dt Ges Geowis 156/1:81-92

Rodriguez-Navarro C, Sebastian E (1996) Role of particulate matter from vehicle exhaust on porous building stones (limestone) sulfation. Sci Total Environ 187:79-91

Sabbioni C (1995) Contribution of atmospheric deposition to the formation of damage layers. Sci Total Environ 167:49-56

Sabbioni C (2003) Mechanism of air pollution damage to stone. In: Brimblecombe $\mathrm{P}$ (ed) The effects of air pollution on the built environment, vol 2. Air Pollut Rev, pp 63-88

Sabbioni C, Zappia G (1992a) Atmospheric-derived element tracers on damaged stone. Sci Total Environ 126:35-48

Sabbioni C, Zappia G (1992b) Decay of sandstone in urban areas correlated with atmospheric aerosol. Water Air Soil Pollut 63:305-316

Saiz-Jimenez C (1993) Deposition of airborne organic pollutants on historic buildings. Atmos Environ 27B:77-85

Schwiete HE, Kastanja P, Ludwig U (1965) Das mörteltechnische und chemische Verhalten verschiedener Trasse und Gesteinsmehle in Verbindung mit Kalk in wässrigen Lösungen. Forschungsbericht des Landes NRW, Nr. 1441, Westdeutscher Verlag, Köln und Opladen

Siegesmund S, Török A, Hüpers A, Müller C, Klemm W (2007) Mineralogical, geochemical and microfabric evidences of gypsum crusts: a case study from Budapest. Environ Geol 52:358-397

Simper M (1990) Geologie und Naturwerksteine Nordrhein-Westfalens. In: Grimm WD (ed) Bildatlas wichtiger Denkmalgesteine der Bundesrepublik Deutschland. Arbeitsheft des Bayerischen Landesamtes für Denkmalpflege, Bd. 50, München, pp 191-201 
Smith BJ, Whalley WB, Fassina V (1988) Elusive solution to monumental stone decay. New Sci 1615:49-53

Snethlage R, Wendler E (1997) Moisture cycles and sandstone degradation. In: Baer NS, Snethlage R (eds) Saving our architectural heritage: conservation of historic stone structures. John Wiley and Sons Ltd, London, pp 7-24

Snethlage R, Wendler E, Klemm DD (1996) Tenside im Gesteinsschutz-Bisherige Resultate mit einem neuen Konzept zur Erhaltung von Denkmälern aus Naturstein. In: Snethlage R (ed) Denkmalpflege und Naturwissenschaft. Natursteinkonservierung I. Ernst und Sohn, Berlin, pp 127-146

Steiger M (2003) Crusts and salts. In: Brimblecombe P (ed) The effects of air pollution on the built environment. Air Pollut Rev 2:133-181

Steiger M (2005) Crystal growth in porous materials: i. The crystallization pressure of large crystals. J Cryst Growth 282:455-469

Thornbush M, Viles H (2004) Integrated digital photography and image processing for the quantification of colouration on soiled limestone surfaces in Oxford, England. J Cult Herit 5:285-290

Torfs KM, Van Grieken RE (1997) Chemical relations between atmospheric aerosols, deposition and stone decay layers on historic buildings at the Mediterranean coast. Atmos Environ $31: 2179-2192$

Török A (2003) Surface strength and mineralogy of weathering crusts on limestone buildings in Budapest. Build Environ 38:1185-1192

Török A (2008) Black crusts on travertine: factors controlling development and stability. Environ Geol 56:583-597

Török A, Licha T, Simon K, Siegesmund S (2011) Urban and rural limestone weathering; the contribution of dust to black crust formation; examples from Germany and Hungary. Environ Earth Sci 63:675-693

Trudgill ST, Viles HA, Inkpen R, Moses C, Gosling W, Yates T, Collier P, Smith DI, Cooke RU (2001) Twenty-year weathering remeasurements at St Paul's Cathedral, London. Earth Surf Processes Landf 26:1129-1142

Turpin BJ, Huntzicker JJ (1995) Identification of secondary organic aerosol episodes and quantification of primary and secondary organic aerosol concentrations during SCAQS. Atmos Environ 29:3527-3544

UBA (2011) Umweltdaten. Fachgebiet II Deutsches Umweltbundesamt, Dessau

Vieten K (1961) Die Trachyt-Latit-Alkalibasalt-Assoziation des Siebengebirges am Rhein. University of Bonn, Diss
Viles HA (1994) Observations and explanations of stone decay in Oxford, UK. In: Thiel MJ (ed) Conservation of stone and other materials, vol I, causes of disorders and diagnosis. E and FN Spon-RILEM, London, pp 115-120

von Plehwe-Leisen E, Leisen H, Wendler E (2007) Der DrachenfelsTrachyt-ein wichtiges Denkmalgestein des MittelaltersUntersuchungen zur Konservierung. Z.dt.Ges. Geowis. 158/3: 985-998

Warscheid T, Petersen K, Krumbein WE (1990) A rapid method to demonstrate and evaluate microbial activity on decaying sandstone. Stud Conserv 35:137-147

Wierzchos J, Ascaso C (1998) Mineralogical transformation of bioweathered granitic biotite, studied by HRTEM: evidence for a new pathway in lichen activity. Clay and Clay Min 46(4):446452

Wiese U, Behlen A, Steiger M (2012) The influence of relative humidity on the $\mathrm{SO}_{2}$ deposition velocity to building stones: a chamber study at very low $\mathrm{SO}_{2}$ concentration. Environ Earth Sci. doi: $10.1007 / \mathrm{s} 12665-012-1872-\mathrm{z}$

Wihr R (1986) Restaurierung von Steindenkmälern. Callwey, München, p 236

Winkler EM (1970) The importance of air pollution in the corrosion of stone and metals. Eng Geol 4:327-334

Winkler EM (1975) Stone: properties, durability in man's environment. Springer, New York

WMO-UN World Meteorological Organisation 2012

Wolff A (1972) Die Gefährdung des Kölner Doms-Seine Steine und ihr Zustand im Jahr 1972. Kölner Domblatt 32:7-28

Wolff A (1986) Stone deterioration on the Cathedral of Cologne: Paper, presented at the symposium "air pollution and conservation", Rome

Wolff A (1992) Dombaubericht von Oktober 1991 bis September 1992: 10.1 Londorfer Basaltlava und Schlaitdorfer Sandstein. Kölner Domblatt 57:89-93

Wolff A (2004) Steine für den Dom. In: Schock-Werner B, Lauer S (eds) Steine für den Kölner Dom. Dom Vlg, Köln, pp 8-21

Wolff A, Luckat S (1973) Untersuchungen zur Einwirkung von Luftverunreinigungen auf die Baumaterialien des Kölner Domes. In: Proceedings of the third international clean air congress. VDI-Verlag, Düsseldorf pp A90-A92

Zappia G, Sabbioni C, Gobbi G (1998) Effects of carbonaceous particles and heavy metals on mortar- $\mathrm{SO}_{2}$ reactions. RILEM Mater Struct 31:480-486 